\title{
The Classification and Market Pricing of the Cash Flows and Accruals on Trading Positions
}

June, 2005

Stephen G. Ryan*

X. Jenny Tucker**

Paul A. Zarowin*

* Stern School of Business, New York University. **Fisher School of Accounting, University of Florida. We appreciate comments from seminar participants at the University of Minnesota, especially John Dickhaut and Frank Gigler, two anonymous referees, and Patricia Dechow, the associate editor. 


\title{
The Classification and Market Pricing of the Cash Flows and Accruals on Trading Positions
}

\begin{abstract}
We investigate whether the market prices the change in net trading assets as an operating or nonoperating activity or some mixture of the two, and whether this market pricing is consistent with the (fundamental) association of the change in net trading assets with future cash flows from operations. Our investigation is motivated by the observation that - despite the classification of the cash flows on trading positions as operating under FAS 102 - trading is economically a hybrid operating/non-operating activity. Reflecting this hybrid nature, we hypothesize and find that the change in net trading assets has a less positive association with returns and future CFO than do the pure operating components of cash flows and accruals, and that it has a more positive association with returns and future CFO than do the pure non-operating components of cash flows. To the best of our knowledge, our paper is the first to propose and test hypotheses about the valuation implications of such hybrid cash flows and accruals.
\end{abstract}




\section{The Classification and Market Pricing of the Cash Flows and Accruals from Trading}

\section{INTRODUCTION}

We investigate whether the market prices the change in net trading assets (trading assets minus trading liabilities) ${ }^{1}$ as an operating or non-operating activity or some mixture of the two, and whether this market pricing is consistent with the (fundamental) association of the change in net trading assets with future cash flows from operations. Our investigation is motivated by the observation that - despite the classification of the cash flows on trading positions as operating under FAS 102 (1989) - trading is economically a hybrid operating/non-operating activity. Most notably, the change in net trading assets equals the unrealized gain, a primarily operating item, plus the net principal cash outflow, a primarily non-operating item, for net trading assets during the period. As discussed below, our hypotheses and tests are based on the maintained assumption, supported by theory and empirical research, that operating activities have stronger implications for returns and future cash flow from operations than do non-operating activities.

In concept, the operating aspects of trading pertain to the generation of trading revenue, whether gains and losses or fees, and whether realized cash flows or unrealized accruals. Accounting standards focus on the revenue generating/operating aspects of trading. For example, FAS 115 (1993) defines trading as "active and frequent buying and selling...with the objective of generating profits [i.e., gains] on short-term differences in price." FAS 119 (1994) also includes dealing in the definition of trading; dealers typically focus on generating some form of fee income (e.g., commissions or spreads) rather than gains. The non-operating aspects of trading

\footnotetext{
${ }^{1}$ Trading assets include trading securities, derivative assets not designated as accounting hedges, and other trading assets (e.g., commodity contracts). Trading liabilities include derivative liabilities not designated as accounting hedges and other trading liabilities. Throughout our sample period 1991-2003, banks were required to account for trading assets and liabilities at fair value under the AICPA Audit and Accounting Guides for Banks and Savings Institutions and for Brokers and Dealers in Securities or other accounting standards (e.g., FAS 115 and FAS 133).
} 
pertain to the initial principal cash flows from investing in trading assets or financing through trading liabilities, and to the subsequent return or repayment of principal. In practice, however, the operating and non-operating aspects of trading are inseparable, because the generation of trading revenue often requires traders to take positions with initial principal.

Based on the accounting and financial economic theory and empirical research summarized in Section III, we expect that share returns and future cash flow from operations are positively associated with current cash flow from operations and accruals, because the operating activities that give rise to cash flow from operations (CFO) and accruals tend to be both persistent and positive present value. In contrast, we expect that returns and future CFO have a near zero association with cash flows from investing (CFI) and financing (CFF), because the non-operating activities that give rise to CFI and CFF tend to be close to zero net present value. Reflecting the hybrid nature of trading described above, we hypothesize and find that the change in net trading assets has: (1) a less positive association with returns and future CFO than do the pure operating components of cash flows and accruals, and (2) a more positive association with returns and CFO than do the pure non-operating components of cash flows. To the best of our knowledge, our paper is the first to propose and test hypotheses about the valuation implications of such hybrid cash flows and accruals.

While our research question applies to all firms engaging in trading, we examine a sample of 37 U.S. banks that hold appreciable amounts of trading assets. We choose this sample, because it is the largest available set of fairly homogeneous publicly traded firms with appreciable trading positions.

We conduct three additional empirical analyses to investigate further the valuation implications of hybrid operating/non-operating flows. First, as a benchmark for our results 
regarding trading positions, we examine the association between the change in held-for-sale (HFS) loans and both returns and future CFO. In our view, HFS loans constitute the closest and economically most important analogue to trading positions for our banking sample. Like trading, originating HFS loans is a hybrid operating and non-operating activity. We expect the nonoperating aspects of HFS loans to be relatively more important than for trading, however, because most HFS loans are residential mortgages or consumer loans that are originated and sold in highly competitive markets, rendering this activity closer to zero present value. We hypothesize and find that returns and future CFO are less positively associated with the change in HFS loans than with the change in net trading assets.

Second, in our primary empirical analysis described above, we examine the valuation implications of the aggregate change in net trading assets, instead of its primarily operating (unrealized gain) and non-operating (principal cash flow) components. We do this primarily because we generally cannot separately observe unrealized gains and the principal cash flows on trading positions, although it also is consistent with the inseparability of the operating and nonoperating aspects of trading mentioned above. We can observe trading revenue for a subset of observations, however, and for these observations we use this variable as a proxy for unrealized gains on net trading assets during the period. We hypothesize and find that returns and future CFO are more positively associated with trading revenue than with the remainder of the change in net trading assets.

Third, to address potential heterogeneity in our sample, and to examine whether the market differentiates firms based on the relative operating nature of their activities, we decompose the sample into six large derivatives dealers with both trading assets and liabilities and 31 non-dealer banks with only trading assets. Due to the dealers' greater focus on fee 
generation, we expect their activities generally to be more operating in nature than those of the non-dealer banks. As expected, we find that returns and future CFO are more positively associated with ordinary $\mathrm{CFO}$ and accruals (i.e., the portion of $\mathrm{CFO}$ and accruals not attributable to net trading assets or HFS loans) and with the change in HFS loans for dealers than for nondealer banks. Unexpectedly, however, we find no difference in the market pricing of the change in net trading assets and only a marginally significant (at the $10 \%$ level) difference in the association of future $\mathrm{CFO}$ with the change in net trading assets for dealers and non-dealer banks.

Our results generally support the conclusion that the market appreciates the hybrid natures of the cash flows and accruals associated with trading positions and also with HFS loans, and can differentiate firms based on the relative operating character of their activities. This appreciation likely reflects in part the fact that these items are disclosed separately from other cash flows and accruals in banks' financial reports, and so investors can adjust their valuation analyses for these items. Our results imply that it is important that the cash flows and accruals for activities with hybrid natures be reported in a disaggregated fashion on the statement of cash flows (SCF) or elsewhere in financial reports, regardless of how these items are classified.

Our results bear on two related, important, and timely financial reporting issues. First, the proper classification of cash flows on trading positions is of current interest due to recent highly publicized cases in which Enron and other firms issued liabilities with initial principal specifically, prepaid derivatives or commodity contracts (prepays) - that they classified as trading and for which the cash received at issuance was classified in CFO. In a prepay, one firm receives cash at the inception of the contract in exchange for the promise of future delivery of cash, commodities, or other assets to its counterparty. As such, prepays involve financing. 
Addressing the cash flow classification issues raised by prepays, FAS 149 (2003) requires that if a derivative contains "an other-than-insignificant financing element...at inception, then the borrower shall report all cash inflows and outflows associated with that derivative" as financing. It seems likely that FAS 149's classification requirement will be applied by analogy to all trading liabilities, prepays in particular, regardless of whether they are deemed derivatives for accounting purposes or not. This classification is the opposite of the operating classification of the principal cash flows on trading liabilities during our sample period. Our analysis and results imply that the classification of the cash flows on trading positions as either operating or nonoperating is inherently limited. We discuss possible remedies for this problem in the conclusion.

Second, the distinction between operating and non-operating activities made in FAS 95 (1987) is inherently limited for trading firms and most types of financial institutions whose operations primarily involve investing and financing. ${ }^{2}$ For such firms, operating and nonoperating activities are better viewed as ends of a continuum, with different types of activities falling at different places along the continuum. In this study, we focus on the market's perception of where trading activities, which FAS 102 (1989) views as operating, fall along this continuum. We adopt this focus because in our view trading constitutes the most salient example of the phenomena we wish to describe and explain.

As discussed in the conclusion, our study has implications for analysis of the broad set of trading firms and financial institutions that have cash flows with hybrid natures that are not fully captured by their classification as operating on the SCF. These firms play a large and increasing role in the overall economy. Moreover, our study may have implications for the somewhat

\footnotetext{
${ }^{2}$ See Ryan (2002) for elaboration of this point in the contexts of various types of financial institutions.
} 
analogous SCF classification issues that arise for non-financial firms as well. These implications merit future research. ${ }^{3}$

The remainder of the paper is organized as follows. Section II summarizes the related prior literature and our contributions to that literature. Section III discusses the GAAP regarding SCF classification for trading positions and HFS loans during our sample period, and justifies and states our hypotheses. Section IV describes our sample, defines our cash flow and accrual components, and discusses the descriptive statistics. Section V develops our returns and future CFO regression equations, restates our hypotheses as coefficient restrictions in those equations, and reports the results of estimating these equations. Section VI reports the results of specification analyses distinguishing trading revenues from principal cash flows and dealers from non-dealer banks and describes various robustness tests. Section VII concludes.

\section{PRIOR LITERATURE}

A large literature examines the market pricing of cash flows and either earnings or accruals for broad samples generally restricted to non-financial firms. ${ }^{4}$ More recently, Dechow, Kothari, and Watts (1998) and Barth, Cram, and Nelson (2001) examine the ability of CFO and either earnings or accruals to predict future CFO. Of this literature, the most related paper to ours is Livnat and Zarowin (1990), which is the only prior paper to examine the valuation implications of the components of cash flow. For a sample of non-financial firms, Livnat and Zarowin predict that the market prices CFO, CFI, CFF, and accruals differently, and they find

\footnotetext{
${ }^{3}$ For example, non-financial firms' classification of the following cash flows as operating under FAS 95 and FAS 102 has been criticized by many academics and practitioners (e.g., see Nurnberg 1993): interest receipts and expenditures, dividend receipts, expenditures for inventory to stock newly opened stores, and installment sales receipts. Of these examples, installment sales, which involve both operations and financing, exhibit a nature closest to the hybrid nature of trading.

${ }^{4}$ See, for example, Wilson (1986,1987), Bowen, Burghstahler, and Daley (1987), Rayburn (1987), Bernard and Stober (1989), Ali (1994), and Dechow (1994).
} 
that returns are significantly positively associated with both CFO and accruals, less strongly but significantly negatively associated with CFI, and insignificantly positively associated with CFF. Consistent with Livnat and Zarowin's returns analysis, for samples of non-financial firms, Dechow, Kothari, and Watts (1998) and Barth, Cram, and Nelson (2001) find that CFO and (the components of) accruals are significantly positively associated with future CFO. We contribute to this literature by developing and testing directional hypotheses about the valuation implications of certain components of cash flows and accruals, and by showing that the existing classification of the components of cash flows and accruals associated with trading and also HFS loans does not fully reflect their hybrid nature.

A number of papers examine the valuation implications of specific components of net income for financial institutions. For example, for samples of property-casualty insurers, Foster (1977) examines the market pricing of the underwriting, investment, and capital gains components of net income, and Beaver and McNichols (2001) examine the market pricing of the CFO, accrual, and loss reserve development components of net income. For samples of banks, Barth, Beaver, and Wolfson (1990) examine the market pricing of earnings before security gains and losses and realized security gains and losses, Barth (1994) examines the market pricing of these variables and also unrealized security gains and losses, and Wahlen (1994) examines the market pricing and future $\mathrm{CFO}$ implications of earnings before the provision for loan losses, the provision for loan losses, and various other loan default variables. We contribute to this literature by being the first study to examine the market pricing of components of cash flows and accruals for a class of financial institutions, for whom the distinction between operating and nonoperating activities and thus the classification of cash flows as operating or non-operating is likely to be problematic. 
Very little accounting research has been done on trading firms of any kind, despite their increasing importance in the overall economy. The sole exceptions of which we are aware are studies by Jorion (2002) and Liu, Ryan, and Tan (2004) on the risk-relevance of banks' Value-atRisk disclosures for their trading portfolios. These papers relate to our study insofar as they are affected by some of the same economic and financial reporting phenomena that motivate our analysis, for example, banks' matching of trading assets and liabilities. We contribute beyond these papers by providing new insights into the distinct nature of trading firms, in particular, how their trading positions and HFS loans blur the usual distinctions between operating and nonoperating activities.

Finally, Hopkins (1996) is motivated by the behavioral idea that investors' assessment of financial statement items with hybrid natures may be affected by how these items are classified on financial statements. ${ }^{5}$ To the best of our knowledge, our paper is the first market-based study of the relation between market pricing and cash flow statement classification for hybrid items, and it is one of the few studies of the market pricing effects of any financial statement classification. ${ }^{6}$

\section{RELEVANT GAAP AND HYPOTHESES}

\section{Relevant GAAP}

The fact that certain activities have both operating and non-operating aspects is recognized in various ways in the GAAP and accounting practices governing the classification of

\footnotetext{
${ }^{5}$ John Dickhaut points out to us that classification can affect market prices even under models with fully rational investors depending on the specific process by which prices form, and so behavioral theories are not the only possible reason why classification might matter. We believe his point is worthy of future research by accounting theorists, who up to this point have not focused on the effects of financial statement classification.

${ }^{6}$ The only other studies on the effect of classification on market pricing of which we are aware are Cheng, Frischmann, and Warfield (2000) and Linsmeier, Shakespeare, and Sougiannis (2000), who examine the association between market value and hybrid financing instruments classified in various ways.
} 
cash flows. FAS 95 provides intuitive and well-known characterizations of investing and financing activities that we do not repeat here. Rather than defining operating activities directly, paragraph 21 of FAS 95 defines operating activities as a catchall or default category that includes "all transactions and other events that are not defined as investing or financing activities." This suggests that transactions with hybrid natures that do not cleanly fall into the investing or financing categories should be classified as operating. However, in paragraph 24 of FAS 95, the FASB acknowledges that "[c]ertain cash receipts and payments may have aspects of more than one class of cash flows", stating "[i]f so, the appropriate classification shall depend on the activity that is likely to be the predominant source of cash flows for the item.",

In FAS 102, the FASB decided that the predominant characteristics of trading positions and HFS loans are operating, requiring in paragraphs 8 and 9 of FAS 102 that the cash flows on assets "acquired specifically for resale and ... carried at market value in a trading account" and loans "originated or purchased specifically for resale and ... held for short periods of time" be classified as operating. In paragraph 26 of FAS 102, the FASB justified this requirement stating that these assets are "similar to inventory in other businesses." No GAAP rule developed prior to the issuance of FAS 149 in April 2003 specifically considers the classification of the cash flows from trading liabilities with initial value or any other type of liability that has both operating and financing aspects. Prior to FAS 149, the practice for our sample of banks (and, in our understanding, for trading firms generally) was to classify the cash flows on trading liabilities as

\footnotetext{
${ }^{7}$ In paragraphs 93-95 of FAS 95, the FASB provides the example of installment sales - which have both operating and investing characteristics for the seller - to illustrate how the predominant characteristics should be determined. The FASB concludes that the predominant characteristic of installment sales is operating, stating "cumulative cash flow from operating activities over the life of an enterprise that finances most of its sales under installment plans might be negative." In reaching this conclusion, the FASB appears to be primarily concerned with the usefulness of $\mathrm{CFO}$ as a performance measure.
} 
operating, consistent with the classification of the cash flows on trading assets. As discussed in the introduction, this practice likely will change due to the issuance of FAS 149.

\section{Hypotheses}

We expect the associations of returns and future CFO with the cash flows and accruals resulting from an activity to rise with the persistence of that activity and with the extent to which that activity is positive present value (or is associated with other positive present value activities not included in the estimation model). We expect operating activities to be more persistent and/or positive present value on average than are non-operating activities, for three reasons. First, this expectation is consistent with the August 1999 G4+1 discussion paper on reporting financial performance, paragraph 2.12 of which concludes that operating activities tend to be "recurring" and "value adding," among other characteristics. Second, this expectation is consistent with the theoretical irrelevance of financing activities postulated by Miller and Modigliani (1958). Relatedly, it is also consistent with various financial economic theories discussed by Livnat and Zarowin (1990) that imply investing and financing activities could be either positive or negative present value, with these effects possibly offsetting. ${ }^{8}$ Third, it is consistent with Livnat and Zarowin's finding that returns are significantly positively associated with CFO and accruals, are less strongly but significantly negatively associated with CFI, and are insignificantly positively associated with CFF, and with Dechow, Kothari, and Watts (1998) and Barth, Cram, and Nelson's (2001) finding that future CFO is significantly positively associated with CFO and (the components of) accruals.

\footnotetext{
${ }^{8}$ For example, Miller and Rock (1985) argue that CFF has negative value implications because the need to raise external funds suggests that future CFO will be lower than previously expected.
} 
For banks, operating activities tend to have a highly repetitive nature, often generate related ongoing streams of fee income, and may involve skill or other comparative advantage that generates positive net present value. This is particularly true for large banks that engage in investment banking and other high-margin services businesses. In contrast, while banks' nonoperating activities also tend to be fairly repetitive, these activities are less likely to be associated with ongoing streams of fee income and are more likely to be closer to zero net present value. In particular, we expect the effects predicted by the financial economic theories discussed by Livnat and Zarowin (1990) regarding the value implications of investing and financing activities to be relatively small (though not necessarily zero) for banks, due to the highly competitive nature and frequency of those activities. For these reasons, we expect banks' returns and future CFO to be more positively associated with their $\mathrm{CFO}$ and accruals than with their non-operating cash flows.

Trading has characteristics of an operating activity insofar as it requires managerial effort and skill to identify mispriced assets and liabilities and to manage complex and interrelated positions, and this effort and skill generates positive net present value through trading gains or services that yield fee income (e.g., dealing, financial advice, and securities custody and processing). Though typically held for a shorter period of time than non-trading assets and liabilities, trading assets (liabilities) also constitute investments (provide financing) for as long as they are held. Thus, trading has both operating and non-operating aspects, although these aspects are inseparable, because the generation of trading revenue often requires traders to take positions with initial principal.

Similarly, HFS loans have characteristics of an operating activity insofar as originating these loans requires managerial effort and skill to solicit and screen borrowers, and insofar as this effort and skill generate positive net present value or are associated with services that yield fee 
income (e.g., loan origination and servicing). Though typically held for a shorter period of time than loans held in portfolio, HFS loans also constitute investments for as long as they are held. Thus, like trading, HFS loans have both operating and non-operating aspects, which are again inseparable.

Trading positions have relatively more of an operating nature than HFS loans, however, for two distinct reasons. First, the management of trading positions both individually and at the portfolio level can be complex, and these positions are more likely to have positive net present value and to be associated with high-margin services. In contrast, most HFS loans are residential mortgages or consumer loans, commodity financial products that are originated, serviced, and sold in highly competitive markets. Second, many types of trading firms (e.g., dealers and arbitrageurs) manage their trading positions at the portfolio level, assuming largely matched positions in trading assets and liabilities, where their trading liabilities both finance and hedge their trading assets. Well-matched trading portfolios require little net investment or provide little net financing, thereby accentuating the operating aspects of those portfolios.

Thus, trading positions and HFS loans are mixtures of operating and non-operating activities, with the mix being tilted relatively more towards operating for trading positions than for HFS loans. Under the maintained assumption that investors have some (though not necessarily a perfect) understanding of these classification issues, we expect the associations of both returns and future CFO with changes in net trading assets and HFS loans to reflect these mixtures. Specifically, we expect returns and future CFO to have relatively high positive associations with the portion of operating cash flows and accruals arising from activities other than trading and HFS loans, a somewhat less positive association with the change in net trading 
assets, a somewhat less positive association still with the change in HFS loans, and relatively small positive or negative associations with CFI and CFF.

\section{SAMPLE, DEFINITIONS, AND DESCRIPTIVE STATISTICS}

\section{Sample}

To be included in our sample, a firm must be a U.S. commercial bank or thrift (hereafter bank) appearing on the 2002 or 2003 Annual Bank Compustat file that has at least $\$ 500$ million in total assets and trading assets equal to at least $1 \%$ of total assets in at least one year in our sample period. Since banks' regulatory capital leverage ratios ${ }^{9}$ average $8-9 \%$ during our sample period, trading assets generally exceed that percentage of owners' equity.

We imposed the conditions on total and trading assets to ensure that the banks had appreciable trading operations. We did not require these conditions to be met in each year for a given bank to in order to preserve time-series data and thus statistical power; this is important in our paper because of our small sample size, because the explanatory variables in all our models are correlated, and because in the future cash flow analysis we allow for serial dependence of residuals. We did not include Citigroup after the 1998 acquisition of Citicorp by Travelers (an insurance company) in the sample, however, due to the concern that banks and insurance companies' cash flows and accruals would have different natures and thus different valuation implications. Table 1 lists the thirty-seven banks (31 commercial banks and six thrifts) that met these conditions and the effect of each of these conditions on the size of our sample.

To the extent possible, we obtained financial report data from Bank Compustat. Since Bank Compustat does not include SCF data, however, for each bank, we manually collected the

\footnotetext{
${ }^{9}$ Banks' leverage ratio for regulatory capital purposes is Tier 1 capital divided by regulatory assets, which roughly corresponds to owners' equity divided by assets.
} 
following variables from the cash flow statements for every year they were available online on the Securities and Exchange Commission's Edgar database: CFO, CFI, CFF, the change in net trading assets, the change in HFS loans, and changes in all other accrual accounts during the year. Since firms first filed financial reports on Edgar in 1993 and cash flow statements include three years of data, our first year of SCF data (for the 7 banks that filed on Edgar in 1993) is 1991. ${ }^{10}$ For 27 (8\%) of our observations, banks did not provide separate line items for the change in net trading assets on their $\mathrm{SCF}$, and in these cases we constructed these line items using the changes in these balance sheet amounts if the banks provided this information in two consecutive years. None of our results change substantively if we drop these observations.

We obtained annual returns from May of the fiscal year to April following the fiscal year, adjusted for stock splits and dividends, denoted R, from the 2003 CRSP Monthly file. Combining the data from Bank Compustat, Edgar, and CRSP yields 330 observations from 1991-2003 with the complete data needed for the main returns regressions analyses.

Our sample contains two distinct subsamples. Six of the largest commercial banks - Bank of America, Bank of New York, Citicorp, FleetBoston, J P Morgan Chase, and Wachovia collectively dominate the global over-the-counter derivatives-dealing markets. Derivatives dealers closely match the value and risk characteristics of their derivatives assets and liabilities. Reflecting this fact, the six dealers have substantial trading liabilities that average about half the amount of their trading assets on average, with the excess of their trading assets over their trading liabilities reflecting their classification of a significant portion of their investment securities as trading. The remaining 31 non-dealer banks have minimal or no trading liabilities,

\footnotetext{
${ }^{10}$ For certain observations, the data taken from the 1993 filings on Edgar for the 1991 and 1992 fiscal years may be restated for mergers accounted for as poolings of interest. In Section VI, we discuss the results of a specification test in which observations are eliminated that appear to have had significant mergers or acquisitions or significantly restated earnings in a year, and obtain similar results.
} 
and their trading assets are primarily securities. To determine the nature and extent of the heterogeneity across the two sub-samples, in addition to testing our hypotheses on the full sample, we test for differences across the two subsamples.

The banks in our sample are individually large, and they hold a high and increasing percentage of the assets of the U.S. banking system. For example, our sample banks held $31 \%$ (25\%) of the assets of U.S. commercial banks (commercial banks and thrifts) in 1995 and $45 \%$ $(38 \%)$ of the assets of U.S. commercial banks (commercial banks and thrifts) in 2003. ${ }^{11}$ Mergers and acquisitions are the primary cause of the rise in these percentages over time. Ignoring our omission of Citigroup after its acquisition by Travelers in 1998, our sample banks held almost all of the trading assets and trading liabilities of the U.S. banking system throughout our sample period.

\section{Definitions of the Cash Flow and Accrual Components}

The banks in our sample all report CFO using the indirect method. This method begins with net income, denoted NI, and then subtracts certain items that for simplicity (but not entirely accurately, as discussed below) we refer to as total accruals, denoted ACC, in order to arrive at CFO. We decompose ACC into the change in net trading assets (trading assets minus trading liabilities), denoted $\triangle \mathrm{TA}$, the change in HFS loans, denoted $\triangle \mathrm{HFS}$, and all other accruals, which we refer to as ordinary accruals, denoted OACC. This breakdown reflects the following representation of the operating section of the cash flow statement:

NI-ACC $=$ NI-OACC $-\Delta$ TA $-\Delta \mathrm{HFS}=\mathrm{CFO}$.

\footnotetext{
${ }^{11}$ Assets for the commercial banking industry are obtained from "Profits and Balance Sheet Developments at U.S. Commercial Banks in 2003", Federal Reserve Bulletin, Spring 2004. Assets for the thrift industry are obtained from 2003 Fact Book: A Statistical Profile of the Thrift Industry, Office of Thrift Supervision, May 2004.
} 
Of the three components of ACC, only OACC reflects pure accruals, i.e., timing differences between NI and CFO. In particular, while $\triangle \mathrm{TA}$ and $\triangle \mathrm{HFS}$ include unrealized gains and losses, which are timing differences, they also include principal cash flows that never affect NI but do affect CFO. For example, $\triangle \mathrm{TA}$ equals a timing difference - the unrealized gain on trading positions during the period - plus a net principal cash outflow - the purchases of net trading assets during the period minus the principal payments on net trading assets during the period minus the cost of net trading assets sold during the period. Ignoring the possibility of default, the principal cash flows on $\triangle \mathrm{TA}$ and $\triangle \mathrm{HFS}$ sum to zero over the lives of those items.

Reworking equation (1) slightly, we define ordinary cash flow from operations, OCFO, as CFO plus $\triangle \mathrm{TA}$ and $\triangle \mathrm{HFS}$, which equals NI minus OACC:

$$
\mathrm{OCFO}=\mathrm{CFO}+\Delta \mathrm{TA}+\Delta \mathrm{HFS}=\mathrm{NI}-\mathrm{OACC}
$$

Just as OACC reflects pure accruals, OCFO reflects pure operating cash flows.

The definitions in equations (1) and (2) correspond to the following analytical reworking of the operating section of the cash flow statement:

$$
\begin{aligned}
& \text { NI } \\
& -\mathrm{OACC} \\
& =\mathrm{OCFO} \\
& -\triangle \mathrm{TA} \\
& \frac{-\triangle \mathrm{HFS}}{=\mathrm{CFO}}
\end{aligned}
$$

In the remainder of the paper, we refer to OCFO and OACC as the operating components of cash flow and accruals, respectively. We refer to $\triangle \mathrm{TA}$ and $\triangle \mathrm{HFS}$ as hybrid operating/non-operating components of cash flow and accruals, where as discussed above $\Delta \mathrm{TA}$ is relatively more operating than $\triangle \mathrm{HFS}$. We refer to $\mathrm{CFI}$ and $\mathrm{CFF}$ as the non-operating components of cash flow. 
To illustrate these definitions, the appendix reports the operating section of M\&T Bank Corporation's 2000 SCF reworked in the fashion described above. For this observation, both $\Delta \mathrm{TA}(\$ 6.9$ million) and $\Delta \mathrm{HFS}$ (\$81.5 million) are positive, with $\Delta \mathrm{HFS}$ being quite large, so that OCFO ( $\$ 435.1$ million) is $26 \%$ more positive than reported CFO ( $\$ 346.6$ million), and OACC ( $\$ 148.9$ million) is $146 \%$ more negative than ACC ( $\$ 60.5$ million). As indicated by the descriptive statistics for these variables discussed below, large differences between the pure operating and reported measures of $\mathrm{CFO}$ and accruals are common in our sample.

As discussed above, $\Delta \mathrm{TA}$ equals (more operating) unrealized gains plus (less operating) principal cash outflows for trading positions during the period. In specification analysis reported in Section VI, we attempt to analyze the distinct valuation consequences of these components of $\Delta$ TA. Specifically, for the observations for which trading revenue, denoted TR, is reported, we use TR as a proxy for the unrealized gain component, so that $\Delta \mathrm{TA}-\mathrm{TR}$ proxies for the principal cash outflow component. Since TR includes unrealized and realized gains and may include some or all fee revenue from trading, TR overstates (understates) unrealized gains by the amount of realized gains (losses), and it overstates unrealized gains by the amount of fee revenue it includes. Since TR measures unrealized gains with error, $\Delta \mathrm{TA}-\mathrm{TR}$ measures the principal cash outflows with an error of the same magnitude but opposite sign. The amount of this error cannot be determined because the realized gain/loss and fee components of trading revenue generally are not disclosed.

\section{Descriptive Statistics}

Table 2 reports descriptive statistics for the regression variables and also for two firm characteristics: total assets and the ratio of trading assets to total assets. Panel A reports these 
statistics for the full sample, while Panels B and C report them for the subsamples of 6 dealers and 31 non-dealer banks, respectively. All of the regression variables other than $\mathrm{R}$ (which is naturally deflated) are deflated by the market value of equity at the beginning of the fiscal year. To mitigate the effect of outliers in the regression analyses, all of the regression variables are winsorized at three standard deviations from their means and descriptive statistics are reported on the winsorized variables.

Panel A shows that, like the rest of the banking industry, the sample banks generally performed well from 1991-2003, as evidenced by positive mean R (.248), CFO (.080), and ACC (.016). Moreover, the mean of OCFO (.177) is more than twice as large as the mean of CFO (.080), because the sample banks grew their net trading assets and HFS loans over the sample period (mean $\triangle \mathrm{TA}=.028$ and mean $\triangle \mathrm{HFS}=.069$ ), depressing $\mathrm{CFO}$ substantially. The standard deviations of $\triangle \mathrm{TA}$ and $\triangle \mathrm{HFS}, .220$ and .339 , are each substantial relative to the standard deviations of CFO and ACC, .438 and .413, suggesting that CFO and ACC are heterogeneously noisy measures of the pure operating components OCFO and OACC, respectively. Consistent with their good performance, the sample banks raised substantial financing (mean $\mathrm{CFF}=.443$ ) and made significant investments (mean $\mathrm{CFI}=-.517)$.

Comparison of Panels $\mathrm{B}$ and $\mathrm{C}$ shows that, as expected, the 6 dealers have much higher mean total assets ( $\$ 264$ billion versus $\$ 32$ billion), mean ratio of trading assets to total assets (.090 versus .017), and mean TR (.082 versus .023) than the 31 non-dealer banks. The dealers have much higher mean CFO (.149 versus .060) and OCFO (.265 versus .152) than the nondealer banks, suggesting better performance, although mean $\mathrm{R}$ is similar for the two subsamples. The dealers grew their trading assets faster (mean $\Delta \mathrm{TA}=.083$ versus .013 ) but their HFS loans slower (mean $\triangle \mathrm{HFS}=.033$ versus .079) than the non-dealer banks. 
Table 3 reports Pearson correlations for the variables in our returns regressions, many of which are significantly correlated. We summarize only the more interesting of these correlations and the underlying phenomena they suggest. R is more highly positively correlated with OCFO (.176) than with CFO (.059) and with ACC (.008) than with OACC (-.076); these differential correlations clearly are driven by the significant positive correlation between $\mathrm{R}$ and $\Delta \mathrm{TA}(.131)$, since the correlation of R and $\triangle \mathrm{HFS}$ is insignificant (-.033). OCFO is positively correlated with both $\triangle \mathrm{TA}(.159)$ and $\triangle \mathrm{HFS}(.083)$, perhaps because banks generating OCFO invest a portion of that cash flow in net trading assets and HFS loans. CFI is negatively correlated with $\Delta \mathrm{TA}$ (-.109), and CFF is positively correlated with both $\Delta \mathrm{TA}(.222)$ and $\Delta \mathrm{HFS}$ (.245), consistent with these activities displacing other investments, perhaps because they are financed through the same sources. CFI and CFF are highly negatively correlated (-.867), consistent with financing inflows being used to fund investing outflows. ${ }^{12}$

The relatively high correlations among the variables imply that it is necessary to have a fairly large sample of observations in order to generate statistically powerful tests in our regression analyses. Given our small number of banks, this requires pooling observations across a sufficient number of years. Since returns are relatively uncorrelated through time $(\rho=.02)$, this pooling should not yield serially correlated residuals or overstated significance levels in our

\footnotetext{
${ }^{12}$ These correlations differ from those for non-financial firms reported in prior research (e.g., Barth, Cram, and Nelson 2001). To illustrate these differences, we estimated the correlations of CFO, ACC, CFI, and CFF from for all the firms on the Compustat industrial tape over our sample period 1991-2003, winsorizing this data at three standard deviations as we do in the paper. We find that the correlation between CFO and ACC is -.24 and the correlation between CFI and CFF is -.53 for this broader sample of firms, i.e., considerably less negative than for our sample. We believe the more negative correlation between CFO and ACC for banks reflect the monetary nature of banks' assets and liabilities, which renders the distinction between cash and accruals less meaningful, since accruals are often very close to cash. We believe the more negative correlation between CFI and CFF for banks reflects their matching of the magnitude of financial assets (investments) and liabilities (financing). On the other hand, we find the correlation between CFO and CFI is -.25 and the correlation between CFO and CFF is -.43 for this broader sample of firms, i.e., considerably more negative than for our banking sample. We believe these more negative correlations reflect non-financial firms compensating more strongly for lower $\mathrm{CFO}$ by either raising funds externally or reducing investments, and vice versa.
} 
returns analysis, and in specification analysis we find that this is not the case. We allow for firstorder autocorrelation of residuals in our future CFO analysis.

\section{PRIMARY RETURNS AND FUTURE CFO ANALYSIS}

\section{Returns Analysis}

In this section, we estimate and compare the market pricing of the sample banks' cash flow and accrual components. We regress share returns for the 12 months ending on April 30 following the fiscal year on these components aggregated in three different ways. First, as a benchmark and to articulate with prior research by Livnat and Zarowin (1990), we estimate a relatively aggregated model with $\mathrm{CFO}, \mathrm{ACC}$, and the non-operating components $\mathrm{CFI}$ and $\mathrm{CFF}$ as explanatory variables. Second, we estimate a disaggregated version of the first model in which the explanatory variables $\mathrm{CFO}$ and $\mathrm{ACC}$ are broken into their operating components, OCFO and OACC, and their hybrid operating and non-operating components, $\triangle \mathrm{TA}$ and $\triangle \mathrm{HFS}$. Third, we estimate a reaggregated version of the second model in which the operating components are replaced with the single explanatory variable $\mathrm{OP}=\mathrm{OCFO}+\mathrm{OACC}$ and the non-operating components are replaced with the single explanatory variable $\mathrm{NONOP}=\mathrm{CFI}+\mathrm{CFF}$.

The third model is attractive both because it corresponds in the most direct fashion to our hypotheses and because by summing CFI and CFF it eliminates the strongest source of multicollinearity among the explanatory variables. For this reason, we tabulate and discuss in detail our hypotheses tests regarding differences between the coefficients on changes in trading assets and HFS loans and the other components of cash flows and accruals only using the third model, although we more briefly discuss the untabulated results for the other models as well. Our inferences are the same if we use the second model, however, because as discussed below we 
find insignificant differences between the coefficients on OCFO and OACC and between the coefficients on CFI and CFF in that model.

Specifically, our first returns model, similar to Livnat and Zarowin's (1990) equation (3), is: ${ }^{13}$

$$
\mathrm{R}_{\mathrm{t}}=\mathrm{a}+\mathrm{b}_{1} \mathrm{ACC}_{\mathrm{t}}+\mathrm{b}_{2} \mathrm{CFO}_{\mathrm{t}}+\mathrm{b}_{3} \mathrm{CFI}_{\mathrm{t}}+\mathrm{b}_{4} \mathrm{CFF}_{\mathrm{t}}+\mathrm{e}_{\mathrm{t}} .
$$

In this and subsequent models, the explanatory variables are all deflated by the beginning of fiscal year market value of equity. Based on our prior discussion and consistent with Livnat and Zarowin's results for their sample of non-financial firms, we expect relatively high positive coefficients on the primarily operating components $\mathrm{ACC}$ and $\mathrm{CFO}$, and we expect relatively small positive or negative coefficients on the non-operating components CFI and CFF. That is, we expect $b_{1} \approx b_{2}>b_{3} \approx b_{4} \approx 0$. When our hypotheses about the signs of and differences between coefficients are directional, as is usually the case, we say a coefficient or difference of coefficients is significant if the significance level is $5 \%$ or better in a one-tailed test (i.e., $t \geq 1.65$ ). Otherwise, we evaluate significance at the $5 \%$ level in a two-tailed test (i.e., $t \geq 1.96$ ).

Table 4 reports the estimations of the primary returns and future CFO models. As mentioned above, all regression variables are winsorized at three standard deviations from their means. In addition, Cook's D test was used to check for any additional outliers in each model. No outlier was identified in the returns regressions, but one outlier was identified in the future CFO regressions and deleted.

\footnotetext{
${ }^{13}$ Livnat and Zarowin (1990) use first differences of (the components of) annual cash flow and accruals as the explanatory variables in their main returns models. In contrast, our explanatory variables are in levels form, because this form appears to yield measures closer to the unexpected portions of those variables for our sample; in particular, the levels variables have higher associations with returns both individually and collectively (i.e., in terms of model $\mathrm{R}^{2}$ ). We attribute the superior power of the levels specification in our setting in part to our decomposition of CFO into OCFO $+\Delta \mathrm{TA}+\Delta \mathrm{HFS}$. If we used a first-differenced model, then the second differences $\Delta(\Delta \mathrm{TA})$ and $\Delta(\Delta \mathrm{HFS})$ would be explanatory variables. These second differences do not correspond well to the unexpected portions of these variables, presumably due to over-differencing. In any event, our results for equation (3) are quite consistent with those of Livnat and Zarowin for their returns model, as discussed below, supporting our specification.
} 
The estimation of equation (3) is reported in the first column of Panel A. The coefficients on the primarily operating components are significantly and similarly positive, with coefficients of .510 ( $\mathrm{t}=2.9)$ on CFO and .611 ( $\mathrm{t}=3.3)$ on ACC, and with these coefficients being insignificantly different from each other. In contrast, the coefficients on the non-operating components are significantly and similarly negative, with coefficients of $-.127(t=-2.4)$ on CFI and $-.098(\mathrm{t}=-1.9)$ on CFF, and with these coefficients being insignificantly different from each other. The coefficients on each of CFO and ACC are significantly more positive than the coefficients on each of CFI and CFF. These results are consistent with our hypotheses that returns have a relatively strong positive association with the primarily operating components $\mathrm{CFO}$ and $\mathrm{ACC}$ and a relatively weak association with the non-operating components CFI and CFF. These results are qualitatively similar to those of Livnat and Zarowin (1990) for nonfinancial firms.

Our second, disaggregated returns model is:

$$
\mathrm{R}_{\mathrm{t}}=\mathrm{a}+\mathrm{b}_{1} \mathrm{OACC}_{\mathrm{t}}+\mathrm{b}_{2} \mathrm{OCFO}_{\mathrm{t}}+\mathrm{b}_{3} \Delta \mathrm{TA}_{\mathrm{t}}+\mathrm{b}_{4} \Delta \mathrm{HFS}_{\mathrm{t}}+\mathrm{b}_{5} \mathrm{CFI}_{\mathrm{t}}+\mathrm{b}_{6} \mathrm{CFF}_{\mathrm{t}}+\mathrm{e}_{\mathrm{t}} .
$$

Based on our prior discussion, we expect relatively high positive coefficients on the operating components OACC and OCFO, a lower positive coefficient on $\triangle \mathrm{TA}$, a still lower positive coefficient on $\triangle \mathrm{HFS}$, and relatively small positive or negative coefficients on the non-operating components CFI and CFF. That is, we expect $b_{1} \approx b_{2}>b_{3}>b_{4}>b_{5} \approx b_{6} \approx 0$.

The second column of Table 4, Panel A reports the results of estimating equation (4). Consistent with our predictions, the coefficients on the operating components are significantly and similarly positive, with a coefficient of $.567(\mathrm{t}=3.2)$ on OCFO and a coefficient of .632 $(\mathrm{t}=2.8)$ on $\mathrm{OACC}$, and with these coefficients being insignificantly different from each other. In contrast, the coefficients on the non-operating components are significantly and similarly 
negative, with coefficients of $-.114(\mathrm{t}=-2.2)$ on CFI and $-.092(\mathrm{t}=-1.8)$ on CFF, and with these coefficients being insignificantly different from each other. The coefficients on OCFO and OACC are both significantly more positive than the coefficients on each of CFI and CFF. The coefficient on the hybrid operating/non-operating component $\Delta \mathrm{TA}$ is significantly positive at $.324(t=2.9)$. As predicted, this coefficient is significantly lower than the coefficients on the operating components $\mathrm{OCFO}$ and $\mathrm{OACC}$, and it is significantly higher than the coefficients on the hybrid operating/non-operating component $\Delta \mathrm{HFS}$ and on the non-operating components CFI and CFF. The coefficient on the hybrid operating/non-operating component $\triangle \mathrm{HFS}$ is insignificantly positive at .021. As predicted, this coefficient is significantly lower than the coefficients on the operating components OCFO and OACC and on the hybrid operating/nonoperating component $\Delta \mathrm{TA}$, but it is insignificantly higher than the coefficients on the nonoperating components $\mathrm{CFI}$ and $\mathrm{CFF}$.

Our third, reaggregated returns model is:

$$
\mathrm{R}_{\mathrm{t}}=\mathrm{a}+\mathrm{b}_{1} \mathrm{OP}_{\mathrm{t}}+\mathrm{b}_{2} \Delta \mathrm{TA}_{\mathrm{t}}+\mathrm{b}_{3} \Delta \mathrm{HFS}_{\mathrm{t}}+\mathrm{b}_{4} \mathrm{NONOP}_{\mathrm{t}}+\mathrm{e}_{\mathrm{t}}
$$

Based on our prior discussion, we expect relatively high positive coefficients on OP, a lower positive coefficient on $\Delta \mathrm{TA}$, a still lower positive coefficient on $\Delta \mathrm{HFS}$, and a relatively small positive or negative coefficient on NONOP. That is, we expect $b_{1}>b_{2}>b_{3}>b_{4} \approx 0$.

The third column of Table 4, Panel A reports the results of estimating equation (5). Student $t$ tests of the differences between the coefficients are reported in Table 4, Panel B. Notice that equation (5) has a higher adjusted $\mathrm{R}^{2}$ than equation (4); moreover, this model has a higher adjusted $\mathrm{R}^{2}$ that any other model that involves aggregation of the explanatory variables in equation (4) and it loses almost no raw $\mathrm{R}^{2}$ compared to the disaggregated equation (4). Thus, equation (5) is the best specified of the returns models. 
Consistent with our predictions, the coefficient on OP is significantly positive at .616 $(t=3.7)$. The coefficient on NONOP is significantly negative at $-.089(t=-1.9)$. The coefficient on the hybrid operating/non-operating component $\Delta \mathrm{TA}$ is significantly positive at $.321(\mathrm{t}=3.2)$. As predicted, this coefficient is significantly lower than the coefficient on OP at the $10 \%$ level $(\mathrm{t}=1.5)$. As predicted, this coefficient is significantly higher than the coefficients on $\triangle \mathrm{HFS}$ $(\mathrm{t}=2.6)$ and NONOP ( $\mathrm{t}=3.3)$. The coefficient on the hybrid operating/non-operating component $\triangle \mathrm{HFS}$ is insignificantly positive at .021 . As predicted, this coefficient is significantly lower than the coefficients on OP $(t=3.0)$ and $\Delta T A(t=2.6)$. As predicted, this coefficient is higher than the coefficient on NONOP, though insignificantly so.

In summary, all of the differences of coefficients in equation (5) have the correct sign, with the all the coefficient differences being significant at the $5 \%$ level except for difference of the coefficients on OP versus $\triangle \mathrm{TA}$, which is significant at the $10 \%$ level, and the difference of the coefficients on $\triangle \mathrm{HFS}$ versus NONOP, which is insignificant. Given our maintained assumption that operating activities have stronger valuation implications than non-operating activities, these results imply that the market prices $\mathrm{OP}$ and $\Delta \mathrm{TA}$ as significantly more operating in nature than $\triangle \mathrm{HFS}$ and NONOP. The marginally significant coefficient difference for OP versus $\Delta \mathrm{TA}$ suggests that the market prices hybrid trading activities as having a predominantly operating nature, while the insignificant coefficient difference for $\triangle \mathrm{HFS}$ versus NONOP suggests the market price the hybrid activity of originating and selling HFS loans as having a predominantly non-operating nature. 


\section{Future CFO Analysis}

As is common in prior research (e.g., see Wahlen 1994, Dechow, Kothari, and Watts 1998, Barth, Cram, and Nelson 2001, and Kothari 2001), in this section we attempt to corroborate and explain our prior returns results in terms of the (fundamental) association of the change in net trading assets and other components of cash flows and accruals with future CFO. We emphasize that this analysis should be viewed as complementary with, and not subordinate to, the returns analysis. Specifically, the future CFO analysis indicates whether the components of cash flow and accruals are economically distinct, while the returns analysis indicates whether the market perceives these components to be economically distinct. Moreover, as emphasized by prior research, the future CFO analysis is of interest independent of the returns analysis because the FASB (1978) states in paragraph 37 of CON 1 that a primary goal of financial reporting is to "provide information to help investors and creditors and others assess the amounts, timing, and uncertainty of prospective net cash inflows to the related enterprise."

We measure future CFO in year $t$ as the sum of CFO for the years $t+1$ to $t+3$ deflated by market value at the beginning of fiscal year $\mathrm{t}$, denoted $\mathrm{FCFO} 3_{\mathrm{t}} \cdot{ }^{14}$ We measure future $\mathrm{CFO}$ over a period longer than a year both because returns should reflect the changes in the whole vector of future cash flows, and because growth and other factors render the association between the cash flow and accrual components and future CFO in any individual year very noisy. As reported in Table 3, the correlation of FCFO3 with R is .182, significant at the .005 level.

We regress FCFO3 on the same three sets of explanatory variables as in the returns models (3)-(5):

\footnotetext{
${ }^{14}$ To ensure the time value of money does not affect our results, we conducted a specification test using as the dependent variable the present value of CFO in years $t+1$ thorough $t+3$ discounting at a constant $10 \%$ annual rate; aside from having the largely mechanical effect of decreasing the absolute magnitudes of our coefficients, our results are not affected.
} 


$$
\begin{aligned}
& \mathrm{FCFO}_{\mathrm{t}}=\mathrm{a}+\mathrm{b}_{1} \mathrm{ACC}_{\mathrm{t}}+\mathrm{b}_{2} \mathrm{CFO}_{\mathrm{t}}+\mathrm{b}_{3} \mathrm{CFI}_{\mathrm{t}}+\mathrm{b}_{4} \mathrm{CFF}_{\mathrm{t}}+\mathrm{e}_{\mathrm{t}} \\
& \mathrm{FCFO}_{\mathrm{t}}=\mathrm{a}+\mathrm{b}_{1} \mathrm{OACC}_{\mathrm{t}}+\mathrm{b}_{2} \mathrm{OCFO}_{\mathrm{t}}+\mathrm{b}_{3} \Delta \mathrm{TA}_{\mathrm{t}}+\mathrm{b}_{4} \Delta \mathrm{HFS}_{\mathrm{t}}+\mathrm{b}_{5} \mathrm{CFI}_{\mathrm{t}}+\mathrm{b}_{6} \mathrm{CFF}_{\mathrm{t}}+\mathrm{e}_{\mathrm{t}} \\
& \mathrm{FCFO}_{\mathrm{t}}=\mathrm{a}+\mathrm{b}_{1} \mathrm{OP}_{\mathrm{t}}+\mathrm{b}_{2} \Delta \mathrm{TA}_{\mathrm{t}}+\mathrm{b}_{3} \Delta \mathrm{HFS}_{\mathrm{t}}+\mathrm{b}_{4} \mathrm{NONOP}_{\mathrm{t}}+\mathrm{e}_{\mathrm{t}}
\end{aligned}
$$

We expect that components that are more positively related to returns should also be more positively associated with FCFO3. Thus, the hypotheses previously made about the signs of and differences between the coefficients in the returns regressions models apply directly to the future CFO models in this section, and so we do not restate these hypotheses. As for the returns analysis, we tabulate and discuss in detail our hypothesis tests about differences of coefficients on the explanatory variables only for the reaggregated model in equation (8), although we more briefly discuss the untabulated results for the other models as well.

Both because annual CFO is serially correlated and because FCFO3 are measured over overlapping three-year periods, the residuals from OLS estimations of equations (6)-(8) are significantly positively serially correlated; for example, the first-order autocorrelation of the pooled OLS residual in equation $(8)$ is $.65\left(\chi^{2}=58.6\right)$. To address this issue, we estimate these equations using maximum likelihood, allowing the residuals for each firm to follow the same AR(1) process. ${ }^{15}$

\footnotetext{
${ }^{15}$ The actual time-series of the residuals in equations (6)-(8) and subsequent future CFO models likely is more complicated than the AR(1) process we assume in the maximum likelihood estimation. In particular, the measurement of FCFO3 over overlapping three-year periods introduces a MA(2) process into the time-series. Given our relatively small sample size, allowing for such a complicated time-series process for the residuals likely would yield inefficient estimation of the variance-covariance matrix. For this reason, we assume the simpler AR(1) process, and use the appropriate powers of the estimated first-order autocorrelation parameter of .65 as the higherorder autocorrelations of the residuals. This approach appears to work well. For example, in the OLS estimation of equation (8), the estimated second-order autocorrelation of the residuals is .47 while the AR(1) process implies this autocorrelation is $.42=.65^{2}$, and the estimated third-order autocorrelation is .17 while the AR(1) process implies this autocorrelation is $.27=.65^{3}$. As a robustness test, we allowed the coefficients of the AR(1) process to vary by firm. None of our inferences was changed.
} 
The results of all the future CFO regressions are reported in Table 4, Panel A, with equation (6) represented in the fourth column. The coefficients on CFO and ACC are significantly positive at $1.864(\mathrm{t}=4.4)$ and $2.324(\mathrm{t}=5.1)$, respectively, with the two coefficients being insignificantly different. In contrast, the coefficient on the non-operating component CFI is insignificantly negative, and the coefficient on the non-operating component CFF is significantly negative at the $10 \%$ level; these two coefficients are significantly different from each other in large part due to their high positive covariance. Each of the coefficients on $\mathrm{CFO}$ and ACC is significantly more positive than the coefficients on each of CFI and CFF. These results are consistent with our hypotheses that future CFO has a relatively strong positive association with the primarily operating components $\mathrm{CFO}$ and $\mathrm{ACC}$ and a relatively weak association with the non-operating components CFI and CFF.

The fifth column of Table 4, Panel A reports the estimation of equation (7). Consistent with our predictions, the coefficients on the operating components are significantly positive, with a coefficient on OCFO of $2.037(t=4.7)$ and a coefficient on OACC of $1.229(t=2.1)$, with these two coefficients being significantly different. The coefficients on the non-operating components CFI and CFF are insignificantly different from zero; these two coefficients are again significantly different from each other. Each of the coefficients on OCFO and OACC is significantly more positive than the coefficients on each of CFI and CFF. The coefficient on the hybrid operating/non-operating component $\Delta \mathrm{TA}$ is significantly positive at $.854(\mathrm{t}=4.2)$. As predicted, this coefficient is significantly lower than the coefficients on OCFO, though unexpectedly it is insignificantly lower than the coefficient on OACC. As expected, the coefficient on $\Delta \mathrm{TA}$ is significantly higher than the coefficients on the hybrid operating/nonoperating component $\triangle \mathrm{HFS}$ and the non-operating components CFI and CFI. The coefficient on 
the hybrid operating/non-operating component $\Delta$ HFS is significantly positive at $.388(\mathrm{t}=2.1)$. As predicted, it is significantly less than the coefficients on the operating components OCFO and $\mathrm{OACC}$ and on the hybrid operating/non-operating component $\triangle \mathrm{TA}$, and it is significantly higher than the coefficients on the non-operating components CFI (at the 10\% level) and CFF.

The sixth column of Table 4, Panel A reports the results of estimating equation (8). Student $\mathrm{t}$ tests of the differences between the coefficients are reported in Table 4, Panel C. Consistent with our predictions, the coefficient on OP is significantly positive at $1.980(t=4.7)$. The coefficient on NONOP (-.108) is insignificantly negative. The coefficient on the hybrid operating/non-operating component $\Delta \mathrm{TA}$ is significantly positive at $.924(\mathrm{t}=4.9)$. As predicted, the coefficient on $\Delta \mathrm{TA}$ is significantly lower than the coefficient on $\mathrm{OP}(\mathrm{t}=2.5)$, and significantly higher than the coefficients on $\triangle \mathrm{HFS}(\mathrm{t}=1.9)$ and NONOP $(\mathrm{t}=4.6)$. As predicted, the coefficient on the hybrid operating/non-operating component $\Delta \mathrm{HFS}$ is significantly positive at $.486(\mathrm{t}=2.7)$. As predicted, the coefficient on $\triangle \mathrm{HFS}$ is significantly lower than the coefficients on OP $(\mathrm{t}=3.1)$, and $\triangle T A(t=1.9)$. As predicted, the coefficient on $\triangle \mathrm{HFS}$ is significantly higher than the coefficient on NONOP $(\mathrm{t}=2.6)$.

In summary, in the future CFO regression equation (8), all of the coefficient differences have the predicted sign and are significant. Specifically, we find that future CFO has a relatively high positive association with the operating components of cash flow and accruals, a somewhat less positive association with $\Delta \mathrm{TA}$, a somewhat less positive association still to $\Delta \mathrm{HFS}$, and a relatively small positive association with the non-operating components of cash flow.

Summarizing the results of the returns and future CFO analyses, all the coefficient differences have the correct signs in both analyses, consistent with our argument that trading and originating and selling HFS loans constitute hybrid operating/non-operating activities. Moreover, 
the results of estimating the returns regression equation (5) and the future $\mathrm{CFO}$ regression (8) substantially correspond, consistent with the market being aware, at least to some extent, of the hybrid economic natures of trading activities and HFS loans. The primary disparity between the two analyses is the coefficient differences for OP versus $\triangle T A$ and for $\triangle H F S$ versus NONOP are less significant or insignificant in the returns analysis but significant in the future CFO analysis. A possible explanation for this disparity is that investors put somewhat excess weight on the more predominant aspect of the nature of a hybrid activity, i.e., operating for trading activities and non-operating for HFS loan activities.

\section{SPECIFICATION ANALYSES}

\section{Unrealized Gain versus Principal Cash Flows}

As discussed above, $\Delta \mathrm{TA}$ equals the unrealized gain plus the principal cash outflow for trading positions during the period. We hypothesize that the unrealized gain is more operating in nature than the principal cash flow. Because we cannot observe either the unrealized gain or the principal cash flows directly, ${ }^{16}$ however, we use trading revenue as proxy for the unrealized gain. Trading revenue is observable for 260 (79\%) of the 330 sample observations on either Bank Compustat or the Bank Regulatory Y9-C filings. ${ }^{17}$ We emphasize that trading revenue includes realized gains and may include fee income associated with trading; since these additional components of trading revenues are operating in nature, their inclusion does not alter the hypothesis stated above. In addition, banks may differ in the extent to which trading revenue

\footnotetext{
${ }^{16}$ Unrealized gains and losses are not observable due to banks' aggregation of unrealized gains and losses with realized gains and losses and other source of non-interest income. The principal cash flows on trading positions are not directly observable due to the classification of these cash flows as operating and banks' universal use of the indirect method of reporting cash flow from operations.

${ }^{17}$ The Compustat Bank file includes trading revenue for 178 of our observations, and the Bank Regulatory Y9-C database includes trading revenues for an additional 82 of our observations.
} 
includes fee income. For these reasons, trading revenue is a heterogeneously noisy measure of unrealized gains, likely weakening our results.

Given the relatively small size of our sample, to avoid losing the observations for which trading revenue is not available, we set TR equal to trading revenue if it is available and to zero otherwise, and add it as an additional explanatory variable in equations (5) and (8). ${ }^{18}$

$$
\begin{aligned}
& \mathrm{R}_{\mathrm{t}}=\mathrm{a}+\mathrm{b}_{1} \mathrm{OP}_{\mathrm{t}}+\mathrm{b}_{2} \Delta \mathrm{TA}_{\mathrm{t}}+\mathrm{b}_{3} \Delta \mathrm{HFS}_{\mathrm{t}}+\mathrm{b}_{4} \mathrm{NONOP}_{\mathrm{t}}+\mathrm{b}_{5} \mathrm{TR}_{\mathrm{t}}+\mathrm{e}_{\mathrm{t}} \\
& \mathrm{FCFO}_{\mathrm{t}}=\mathrm{a}+\mathrm{b}_{1} \mathrm{OP}_{\mathrm{t}}+\mathrm{b}_{2} \Delta \mathrm{TA}_{\mathrm{t}}+\mathrm{b}_{3} \Delta \mathrm{HFS}_{\mathrm{t}}+\mathrm{b}_{4} \mathrm{NONOP}_{\mathrm{t}}+\mathrm{b}_{5} \mathrm{TR}_{\mathrm{t}}+\mathrm{e}_{\mathrm{t}}
\end{aligned}
$$

In equations (5-TR) and (8-TR), the coefficients $b_{5}$ on TR captures the additional valuation implications of trading revenue, when disclosed, beyond $\Delta \mathrm{TA}$, which includes both the unrealized gain and principal cash flow. We hypothesize that TR is more highly priced than aggregate $\Delta \mathrm{TA}$, so that the coefficients $\mathrm{b}_{5}$ in equation (5-TR) and (8-TR) are positive.

Table 5 reports the results of estimating equations (5-TR) and (8-TR). In equation (5TR), the coefficient on TR is significantly positive at $.723(\mathrm{t}=2.0)$, consistent with our hypothesis that the market prices trading revenue as having a more operating nature than the remainder of $\Delta \mathrm{TA}$. In equation (8-TR), the coefficient on TR is positive and relatively large (.929 compared to a coefficient of .979 on $\Delta \mathrm{TA}$ ), but not significant. The significant coefficient in TR in the returns analysis but insignificant coefficient on TR in the future CFO analysis could be due either to the market overvaluing TR or to the measurement error in TR yielding more attenuation bias in the future $\mathrm{CFO}$ analysis than in the returns analysis.

\footnotetext{
${ }^{18}$ We also estimated analogous models using only the 260-bank sample for which trading revenue is observable, and obtained results similar to those reported in this section. In particular, we estimated versions of (5-TR) and (8-TR) in which we included both TR and the net principal cash outflow estimated as TR- $\Delta$ TA instead of $\Delta$ TA. In both equations, the estimated coefficients on TR were positive and significant, and the coefficients on TR- $\Delta$ TA were close to zero and insignificant.
} 


\section{Dealer versus Non-Dealer Banks}

As discussed above, our sample contains two distinct subsamples: six derivatives dealers with both trading assets and trading liabilities, and 31 non-dealer banks with trading assets only. Reflecting dealers' focus on fee-generation, we expect the dealers to generate more positive net present value fee streams from their operations than do non-dealer banks. Because most of these fee streams (including those for trading) will be reflected in either OCFO or OACC, our primary expectation is that the coefficients on OCFO and OACC are higher for dealers than for nondealer banks. Because dealers match their trading assets and trading liabilities, thereby diminishing the magnitude of net principal cash flows and thus the non-operating aspects of trading, we also expect a higher coefficient on $\Delta \mathrm{TA}$ for dealers than non-dealer banks, Finally, loan origination and other fees for HFS loans that must be deferred under FAS 91 (1986) will be reflected in $\triangle \mathrm{HFS}$; if dealer banks have higher fees of this type, then there should also be a higher coefficient on $\triangle \mathrm{HFS}$ for dealers than for non-dealer banks.

To determine whether these subsamples are in fact heterogeneous in this fashion, we estimate the reaggregated returns and future CFO equations (5) and (8) allowing the coefficients to differ across the two subsamples. ${ }^{19}$ Specifically, we define a dummy variable, D, equal to 1 for the six dealers and zero otherwise. We interact D with the intercept and each of the independent variables in those equations.

$$
\begin{gathered}
\mathrm{R}_{\mathrm{t}}=\mathrm{a}+\mathrm{a}_{\mathrm{D}} \mathrm{D}+\mathrm{b}_{1} \mathrm{OP}_{\mathrm{t}}+\mathrm{b}_{2} \Delta \mathrm{TA}_{\mathrm{t}}+\mathrm{b}_{3} \Delta \mathrm{HFS}_{\mathrm{t}}+\mathrm{b}_{4} \mathrm{NONOP}_{\mathrm{t}} \\
+\mathrm{b}_{5} \mathrm{D}^{*} \mathrm{OP}_{\mathrm{t}}+\mathrm{b}_{6} \mathrm{D}^{*} \Delta \mathrm{TA}_{\mathrm{t}}+\mathrm{b}_{7} \mathrm{D}^{*} \Delta \mathrm{HFS}_{\mathrm{t}}+\mathrm{b}_{8} \mathrm{D}^{*} \text { NONOP }_{\mathrm{t}}+\mathrm{e}_{\mathrm{t}} \\
\mathrm{FCFO}_{\mathrm{t}}=\mathrm{a}+\mathrm{a}_{\mathrm{D}} \mathrm{D}+\mathrm{b}_{1} \mathrm{OP}_{\mathrm{t}}+\mathrm{b}_{2} \Delta \mathrm{TA}_{\mathrm{t}}+\mathrm{b}_{3} \Delta \mathrm{HFS}_{\mathrm{t}}+\mathrm{b}_{4} \mathrm{NONOP}_{\mathrm{t}} \\
+\mathrm{b}_{5} \mathrm{D}^{*} \mathrm{OP}_{\mathrm{t}}+\mathrm{b}_{6} \mathrm{D}^{*} \Delta \mathrm{TA}_{\mathrm{t}}+\mathrm{b}_{7} \mathrm{D}^{*} \Delta \mathrm{HFS}_{\mathrm{t}}+\mathrm{b}_{8} \mathrm{D}^{*} \text { NONOP }_{\mathrm{t}}+\mathrm{e}_{\mathrm{t}} .
\end{gathered}
$$

\footnotetext{
${ }^{19}$ The results of estimating the aggregated equations (3) and (6) and the disaggregated equations (4) and (7), distinguishing dealer and non-dealer banks, yield consistent differences across the dealer and non-dealer bank groups as those for the reaggregated equations (5-D) and (8-D) reported in Table 6.
} 
In these regressions, the coefficients on the uninteracted variables represent the sensitivities for the 31 non-dealer banks; the sums of the coefficients on the uninteracted and interacted variables represent the sensitivities for the 6 dealers. The coefficients on the interacted variables represent the differences in slopes between the dealer and non-dealer bank groups.

Table 6 reports the results of estimating equations (5-D) and (8-D). The significantly positive coefficients on the interacted variables $D^{*} \mathrm{OP}$ and $\mathrm{D}^{*} \Delta \mathrm{HFS}$ in both equations evidence heterogeneity consistent with the more operating character of dealers' operations discussed above. Specifically, the coefficient on $\mathrm{D}^{*} \mathrm{OP}$ is $1.488(\mathrm{t}=2.7)$ in equation $(5-\mathrm{D})$ and $2.487(\mathrm{t}=2.0)$ in equation (8-D), implying OP has greater valuation implications for the 6 dealers than for the non-dealer banks. The coefficient on $\mathrm{D}^{*} \Delta \mathrm{HFS}$ is $.783(\mathrm{t}=2.6)$ in equation $(5-\mathrm{D})$ and $1.316(\mathrm{t}=2.3)$ in equation (8-D), implying $\triangle$ HFS has greater valuation implications for the 6 dealers than for the non-dealer banks. In contrast, the coefficient on the interacted variable $\mathrm{D}^{*} \Delta \mathrm{TA}$ is insignificant in equation (5-D) and significant at the $10 \%$ level in equation (8-D), only partially and weakly consistent with our expectation that trading has a more operating character for dealers than for non-dealer banks.

The consistency of the results across the returns and future cash flow equations in this section again suggests that the market has a general understanding of the different valuation implications of the various cash flow and accrual components.

\section{Other Specification Analyses}

We conducted the following additional specification analyses to ensure that our results are robust. First, banks merged or acquired each other continuously throughout the sample 
period. Pooling mergers yield restatements of historical financial statements, which along with restatements for any other reasons constitute an issue when we collect prior years' data from a given year's financial report filed on Edgar, as discussed in Section IV. To eliminate significant mergers and acquisitions and restatements, we deleted bank-year observations for which assets grew more than $20 \%$ during the year or for which annual earnings from Bank Compustat (originally reported) differs from the annual earnings from Edgar (potentially restated). This eliminated $20 \%$ of the observations in the primary returns analyses. The results are similar for all analyses except for those involving TR reported in Table 5, for which TR becomes insignificant.

Second, as a single industry, the bank-observations are cross-correlated in a given year. In our view, the common industry effects have the same interest as the firm-specific effects, so that removing those effects eliminates variation of interest. However, we also estimated all models using fixed time effects and using a robust variance estimate approach that allows for correlation of residuals across clusters of observations, in this case the observations in a given year. The estimated coefficients have the hypothesized relationships in these analyses, although the $t$ statistics generally diminish by about a third.

\section{CONCLUSION}

In this paper, we argue that banks' trading activities have a hybrid operating/nonoperating nature that was not fully captured by the classification of the cash flows on these activities as operating during our sample period from 1991-2003 under FAS 102 and related accounting practices. Reflecting this hybrid nature, we hypothesize and find that the change in net trading assets has a less positive association with returns and future CFO than do the pure operating components of cash flows and accruals, and that it has a more positive association with 
returns and $\mathrm{CFO}$ than do the pure non-operating components of cash flows. We test and provide support for this hypothesis on a sample of U.S. banks holding an appreciable amount of trading assets.

We conduct three additional empirical analyses to further investigate how the market prices hybrid operating/non-operating flows, and how these flows relate to future CFO. First, we hypothesize and find that the market prices the change in net trading assets as more operating in nature than the change in held-for-sale loans, another important hybrid but more investingoriented activity. Second, for the observations for which we can observe the operating and nonoperating components of the change in net trading assets, we hypothesize and find that returns and future cash flows are more positively associated with the trading revenue (operating) component than with the principal cash flow (non-operating) component. Third, to address potential heterogeneity in our sample, and to examine whether the market differentiates firms based on the relative operating nature of their activities, we hypothesize and find that derivative dealers' activities generally are more operating in nature than are those of non-dealer banks, although the results for the change in net trading assets are only partially and weakly consistent with our hypotheses.

Collectively, our market pricing and future cash flow results suggest that the market appreciates the hybrid operating/non-operating nature of trading activities and also of HFS loans, and that it differentiates firms based on the relative operating nature of their activities. This appreciation likely reflects in part the fact that investors can observe the changes in trading positions and HFS loans separately from other CFO and accruals, and so they can make adjustments for these changes in their valuation analyses. Our results imply that it is important that the cash flows and accruals on activities with hybrid natures, such as trading positions and 
HFS loans, be reported in a disaggregated fashion on the cash flow statement or elsewhere in financial reports, regardless of whether these items are classified as operating.

However, our results also imply that any single classification of the cash flows on trading positions and HFS loans logically cannot capture the hybrid economic natures of these activities. Hence, additional disclosures regarding the natures and financial statement effects of these and other activities with hybrid natures would be useful to investors and other users of financial reports. Specifically, it would be useful to require disclosure of the amounts of principal cash flows and timing differences (unrealized gains and losses) associated with these activities; these amounts generally cannot be inferred from current disclosures of the net changes in these accounts.

Our results contribute to the literature on the market pricing of the components of cash flow and accruals, which until now has primarily focused on non-financial firms. To the best of our knowledge, our paper is the first to hypothesize and document empirically that the cash flow from operations of financial institutions and trading firms include components with hybrid operating/non-operating natures that are priced by the market as such, and it is one of the few studies of the market pricing effects of any financial statement classification. While we examine a relatively small sample of banks with significant trading operations, our results have more general importance because a broad set of financial institutions and trading firms have cash flows with hybrid natures that are not fully captured by their cash flow statement classification. For example, lessors classify the cash flows on operating leases and insurers classify the cash flows on traditional insurance contracts as operating, despite the partly non-operating natures of these activities. Financial institutions and trading firms play a large and increasing role in the overall 
economy, and so the cash flow statement classification issues we examine are likely to become more important over time.

Our results are of high current interest given the recent highly publicized cases in which Enron and other firms issued prepay liabilities that raised funds that were classified as operating cash inflows under prior accounting practices. To eliminate firms' ability to use prepays to increase cash flow from operations, the FASB required in FAS 149 that the cash flows on derivative liabilities with other-than-insignificant initial value be classified as financing, and it is likely that this requirement will be applied to trading liabilities generally. While the FASB's motivation for FAS 149's requirement is clear and understandable, this requirement is conceptually problematic, especially for trading firms with well-matched trading assets and liabilities, because it will cause the cash flows on these trading assets and trading liabilities to be classified inconsistently on the cash flow statement. In particular, growing trading firms will have operating cash outflows for trading assets and financing cash inflows for trading liabilities.

We believe that the FASB should consider remedying this inconsistency by requiring the cash flows on sufficiently well matched trading assets and liabilities to be classified in a consistent fashion on the cash flow statement. There are two ways the FASB could do this: 1) require the cash flows on well-matched trading assets and liabilities to be classified as operating (i.e., partly or wholly undo the requirement of FAS 149 and return to prior accounting practices), or 2) require the (principal) cash flows on trading assets to be classified as investing (i.e., modify the requirements of FAS 102) and on trading liabilities to be classified as financing (analogous to FAS 149). As discussed above, our results imply that the market views the cash flows on trading positions as largely though not entirely operating in nature, and so on this basis the first approach 
appears to be more economically descriptive. On the other hand, the second approach might be more robust to cases in which trading assets and liabilities are not well matched. 


\section{APPENDIX}

Sample Operating Section of Statement of Cash Flows for M\&T Bank Corporation for 2000 (in thousands)

\begin{tabular}{lc}
\hline Net income (NI) & $\$ 286,156$ \\
$\quad$ +Provision for credit losses & 38,000 \\
+Depreciation and amortization of premises and equipment & 30,164 \\
+ Amortization of capitalized serving rights & 24,392 \\
+ Amortization of goodwill and core deposit intangible & 69,576 \\
+ Provision for deferred income taxes & $(5,911)$ \\
+ Asset write-downs & 1,674 \\
-Net gain on sales of assets & $(6,631)$ \\
-Net change in accrued interest receivable (payable) & 25,540 \\
-Net change in other accrued income (expense) & $\underline{(27,901)}$ \\
-Ordinary accruals (-OACC) & \\
$=$ Ordinary cash flow from operations (OCFO) & $\underline{148,903}$ \\
-Net change in trading assets and liabilities (- $\Delta$ TA) & $(6,868)$ \\
-Net change in loans held for sale (- $\Delta$ HFS) & $\underline{(81,549)}$ \\
$=$ Cash flow from operations (CFO) & 346,642 \\
\hline
\end{tabular}

Accruals $(\mathrm{ACC})=\mathrm{OACC}+\Delta \mathrm{TA}+\Delta \mathrm{HFS}=\$-148,903+\$ 6,868+\$ 81,549=\$-60,468$. 


\section{TABLE 1 \\ Sample}

Panel A: Sample Construction

U.S. banks on 2002 or 2003 Bank Compustat

- U.S. banks with less than $\$ 500$ million assets

$\frac{687}{90}$

$=$ U.S. banks that with more than $\$ 500$ million assets

(53)

- U.S. banks with trading assets less than $1 \%$ of total assets

37

$=$ Sample banks

Panel B: Sample Banks

1. Bank of America*

2. Bank of New York*

3. Bank One

4. Bankatlantic\#

5. Chester Vy

6. Citicorp*

7. City National

8. Commerce Bancorp

9. Community West

10. First Defiance Financial\#

11. First Horizon National

12. First Tennessee National

13. Fleetboston Financial*

14. Irwin Financial

15. J P Morgan Chase \& Co*

16. $M \&$ T Bank

17. Massbank\#

18. Mellon Financial

19. National Commerce Financial

20. National Penn
21. Oriental Financial Group

22. Owen Financial\#

23. Popular Inc

24. Republic Bancshares

25. R \& G Financial Group

26. Regions Financial

27. Suntrust Banks

28. State Street

29. Sterling Bancshares

30. Union Planters

31. Unionbancal

32. Wachovia*

33. Webster Financial\#

34. Wells Fargo

35. Wilshire Financial Services Group

36. Woronoco\#

37. Zions Bancorporation

* indicates derivative dealers that report changes in both trading assets and liabilities in the cash flow statements. \# indicates thrifts. 
TABLE 2

Descriptive Statistics

Panel A: Full Sample (330 firm-years)

\begin{tabular}{|c|c|c|c|c|c|}
\hline Variable & Mean & Std. Dev. & Minimum & Median & Maximum \\
\hline $\bar{R}$ & $\overline{0.248}$ & 0.404 & -0.899 & $\overline{0.210}$ & 1.531 \\
\hline $\mathrm{CFO}$ & 0.080 & 0.438 & -1.816 & 0.105 & 1.929 \\
\hline FCFO3 & 0.609 & 0.955 & -2.911 & 0.447 & 4.257 \\
\hline$A C C$ & 0.016 & 0.413 & -1.929 & -0.015 & 2.659 \\
\hline$\Delta T A$ & 0.028 & 0.220 & -1.025 & 0.003 & 1.108 \\
\hline$\triangle H F S$ & 0.069 & 0.339 & -1.646 & 0.000 & 1.925 \\
\hline$O C F O$ & 0.177 & 0.246 & -1.068 & 0.122 & 1.387 \\
\hline$O A C C$ & -0.081 & 0.189 & -0.793 & -0.039 & 0.628 \\
\hline$C F I$ & -0.517 & 1.082 & -4.288 & -0.378 & 3.232 \\
\hline$C F F$ & 0.443 & 1.137 & -3.427 & 0.299 & 4.368 \\
\hline$T R$ & 0.038 & 0.07 & -0.069 & 0.012 & 0.375 \\
\hline Trading \% & 0.031 & 0.052 & 0.000 & 0.013 & 0.328 \\
\hline Total assets & 76,724 & 143,142 & 252.03 & 19,518 & 770,912 \\
\hline
\end{tabular}

Panel B: Dealer Banks (73 firm-years)

\begin{tabular}{|c|c|c|c|c|c|}
\hline Variable & Mean & Std. Dev. & Minimum & Median & Maximum \\
\hline$R$ & 0.267 & 0.363 & -0.450 & 0.238 & 1.463 \\
\hline $\mathrm{CFO}$ & 0.149 & 0.349 & -0.777 & 0.139 & 1.929 \\
\hline FCFO3 & 1.026 & 1.186 & -1.058 & 0.649 & 4.257 \\
\hline$A C C$ & -0.025 & 0.339 & -1.819 & -0.018 & 0.680 \\
\hline$\Delta T A$ & 0.083 & 0.314 & -1.025 & 0.018 & 1.108 \\
\hline$\triangle H F S$ & 0.033 & 0.149 & -0.607 & 0.000 & 0.774 \\
\hline$O C F O$ & 0.265 & 0.262 & -0.155 & 0.191 & 1.387 \\
\hline$O A C C$ & -0.141 & 0.227 & -0.793 & -0.089 & 0.184 \\
\hline$C F I$ & -0151 & 0.960 & -2.172 & -0.288 & 3.232 \\
\hline$C F F$ & 0.012 & 0.968 & -3.427 & 0.106 & 2.018 \\
\hline$T R$ & 0.082 & 0.101 & 0.008 & 0.039 & 0.375 \\
\hline Trading \% & 0.090 & 0.077 & 0.002 & 0.077 & 0.328 \\
\hline Total assets & 263,564 & 216,569 & 39,426 & 200,500 & 770,912 \\
\hline
\end{tabular}


TABLE 2

Descriptive Statistics

(Continued)

\section{Panel C: Non-Dealer Banks (257 firm-years)}

\begin{tabular}{lccccc}
\hline \multicolumn{1}{c}{ Variable } & Mean & Std. Dev. & Minimum & Median & Maximum \\
\hline$R$ & 0.242 & 0.415 & -0.899 & 0.205 & 1.531 \\
CFO & 0.060 & 0.459 & -1.816 & 0.094 & 1.929 \\
FCFO3 & 0.476 & 0.829 & -2.911 & 0.419 & 2.969 \\
ACC & 0.028 & 0.431 & -1.929 & -0.012 & 2.659 \\
$\Delta T A$ & 0.013 & 0.182 & -1.025 & 0.002 & 1.108 \\
$\Delta H F S$ & 0.079 & 0.375 & -1.646 & 0.000 & 1.925 \\
OCFO & 0.152 & 0.236 & -1.068 & 0.117 & 1.382 \\
OACC & -0.064 & 0.173 & -0.793 & -0.031 & 0.628 \\
CFI & -0.620 & 1.094 & -4.288 & -0.419 & 3.232 \\
CFF & 0.565 & 1.153 & -3.427 & 0.377 & 4.368 \\
TR & 0.023 & 0048 & -0.069 & 0.007 & 0.262 \\
Trading \% & 0.017 & 0.030 & 0.000 & 0.010 & 0.265 \\
Total assets & 31,703 & 61,706 & 252 & 11,857 & 387,798 \\
\hline
\end{tabular}

$R$ denotes share return for the 12 months ending on April 30 following the fiscal year end; $C F O$ denotes cash flow from operations; FCFO3 denotes the sum of the next three years' $C F O ; A C C$ denotes total accruals, i.e., the difference between net income and $C F O ; \triangle T A$ denotes the change in net trading assets; $\triangle H F S$ denotes the change in held-for-sale loans; $O C F O$ denotes $C F O+\triangle T A+\triangle H F S ; O A C C$ denotes $A C C-\triangle T A-\triangle H F S$; CFI denotes cash flow from investing; $C F F$ denotes cash flow from financing; $T R$ denotes trading revenue. Trading $\%$ denotes the ratio of trading assets to total assets. Total assets are in millions. All variables other than $R$, Trading $\%$, and Total assets are deflated by beginning-of-year market value of equity.

All variables, except for Trading $\%$ and Total assets, are winsorized at three standard deviations from their means.

For firm-years that do not report the change in held-for-sale loans on the cash flow statement, $\triangle H F S$ is assumed to be zero. The number of non-zero observations for $\triangle H F S$ is 189,21 and 168 for Panels A, B and C, respectively.

The number of observations for FCFO3 is 226, 55 and 172 for Panels A, B and C, respectively. The number of observations for $T R$ is 260, 66 and 194 for Panels A, B and C, respectively. 
TABLE 3

Pearson Correlations

\begin{tabular}{|c|c|c|c|c|c|c|c|c|c|c|}
\hline & $\underline{C F O}$ & FCFO3 & $A C C$ & $\underline{\Delta T A}$ & $\triangle H F S$ & $\underline{O C F O}$ & $\underline{O A C C}$ & $\underline{C F I}$ & $\underline{C F F}$ & $\underline{T R}$ \\
\hline$R$ & .059 & 0.182 & 0.008 & 0.131 & -0.033 & 0.176 & -0.076 & -0.159 & 0.093 & .228 \\
\hline $\mathrm{CFO}$ & & 0.158 & -0.952 & -0.408 & -0.725 & 0.418 & -0.304 & -0.079 & -0.267 & .019 \\
\hline$F C F O 3$ & & & -0.098 & 0.095 & 0.026 & 0.398 & -0.376 & 0.172 & -0.240 & .294 \\
\hline$A C C$ & & & & 0.411 & 0.796 & -0.233 & 0.278 & -0.023 & 0.354 & .032 \\
\hline$\triangle T A$ & & & & & -0.005 & 0.159 & -0.257 & -0.109 & 0.222 & .396 \\
\hline$\triangle H F S$ & & & & & & 0.083 & -0.051 & 0.017 & 0.245 & .002 \\
\hline$O C F O$ & & & & & & & -0.843 & -0.214 & -0.060 & .478 \\
\hline$O A C C$ & & & & & & & & 0.045 & 0.076 & -.450 \\
\hline$C F I$ & & & & & & & & & -0.867 & -.054 \\
\hline$C F F$ & & & & & & & & & & .019 \\
\hline
\end{tabular}

Correlations significant at the 5\% level in a two-tailed test are in boldface.

See the notes to Table 2 for description of the variables. 
TABLE 4

\section{Main Regression Results}

\section{Panel A: Estimation}

$$
\begin{aligned}
& \mathrm{R}_{\mathrm{t}}=\mathrm{a}+\mathrm{b}_{1} \mathrm{ACC}_{\mathrm{t}}+\mathrm{b}_{2} \mathrm{CFO}_{\mathrm{t}}+\mathrm{b}_{3} \mathrm{CFI}_{\mathrm{t}}+\mathrm{b}_{4} \mathrm{CFF}_{\mathrm{t}}+\mathrm{e}_{\mathrm{t}} \\
& \mathrm{R}_{\mathrm{t}}=\mathrm{a}+\mathrm{b}_{1} \mathrm{OACC}_{\mathrm{t}}+\mathrm{b}_{2} \mathrm{OCFO}_{\mathrm{t}}+\mathrm{b}_{3} \Delta \mathrm{TA}_{\mathrm{t}}+\mathrm{b}_{4} \Delta \mathrm{HFS}_{\mathrm{t}}+\mathrm{b}_{5} \mathrm{CFI}_{\mathrm{t}}+\mathrm{b}_{6} \mathrm{CFF}_{\mathrm{t}}+\mathrm{e}_{\mathrm{t}} \\
& \mathrm{R}_{\mathrm{t}}=\mathrm{a}+\mathrm{b}_{1} \mathrm{OP}_{\mathrm{t}}+\mathrm{b}_{2} \Delta \mathrm{TA}_{\mathrm{t}}+\mathrm{b}_{3} \Delta \mathrm{HFS}_{\mathrm{t}}+\mathrm{b}_{4} \mathrm{NONOP}_{\mathrm{t}}+\mathrm{e}_{\mathrm{t}} \\
& \mathrm{FCFO}_{\mathrm{t}}=\mathrm{a}+\mathrm{b}_{1} \mathrm{ACC}_{\mathrm{t}}+\mathrm{b}_{2} \mathrm{CFO}_{\mathrm{t}}+\mathrm{b}_{3} \mathrm{CFI}_{\mathrm{t}}+\mathrm{b}_{4} \mathrm{CFF}_{\mathrm{t}}+\mathrm{e}_{\mathrm{t}} \\
& \mathrm{FCFO}_{\mathrm{t}}=\mathrm{a}+\mathrm{b}_{1} \mathrm{OACC}_{\mathrm{t}}+\mathrm{b}_{2} \mathrm{OCFO}_{\mathrm{t}}+\mathrm{b}_{3} \Delta \mathrm{TA}_{\mathrm{t}}+\mathrm{b}_{4} \Delta \mathrm{HFS}_{\mathrm{t}}+\mathrm{b}_{5} \mathrm{CFI}_{\mathrm{t}}+\mathrm{b}_{6} \mathrm{CFF}_{\mathrm{t}}+\mathrm{e}_{\mathrm{t}} \\
& \mathrm{FCFO}_{\mathrm{t}}=\mathrm{a}+\mathrm{b}_{1} \mathrm{OP}_{\mathrm{t}}+\mathrm{b}_{2} \Delta \mathrm{TA}_{\mathrm{t}}+\mathrm{b}_{3} \Delta \mathrm{HFS}_{\mathrm{t}}+\mathrm{b}_{4} \mathrm{NONOP}_{\mathrm{t}}+\mathrm{e}_{\mathrm{t}}
\end{aligned}
$$

\begin{tabular}{|c|c|c|c|c|c|c|}
\hline \multirow[b]{2}{*}{ Model } & \multicolumn{3}{|c|}{ Returns } & \multicolumn{3}{|c|}{ Future Cash Flows } \\
\hline & (3) & (4) & (5) & $(6)$ & $(7)$ & (8) \\
\hline Intercept & $\begin{array}{c}0.175^{* * *} * \\
(6.4)\end{array}$ & $\begin{array}{c}0.170 * * * \\
(6.0)\end{array}$ & $\begin{array}{c}0.172 * * * \\
(6.4)\end{array}$ & $\begin{array}{c}0.015 * * * \\
(4.2)\end{array}$ & $\begin{array}{c}0.365 * * * \\
(3.5)\end{array}$ & $\begin{array}{c}0.371 * * * \\
(3.1)\end{array}$ \\
\hline$A C C$ & $\begin{array}{c}0.611^{* * *} \\
(3.3)\end{array}$ & & & $\begin{array}{c}2.324 * * * \\
(5.1)\end{array}$ & & \\
\hline $\mathrm{CFO}$ & $\begin{array}{c}0.510 * * * \\
(2.9)\end{array}$ & & & $\begin{array}{c}1.864 * * * \\
(4.4)\end{array}$ & & \\
\hline$O A C C$ & & $\begin{array}{c}0.632 * * * \\
\quad(2.8)\end{array}$ & & & $\begin{array}{c}1.229 * * \\
(2.1)\end{array}$ & \\
\hline$O C F O$ & & $\begin{array}{c}0.567 * * * \\
(3.2)\end{array}$ & & & $\begin{array}{c}2.037 * * * \\
(4.7)\end{array}$ & \\
\hline$O P$ & & & $\begin{array}{c}0.616^{* * *} \\
\quad(3.7)\end{array}$ & & & $\begin{array}{c}1.980 * * * \\
(4.7)\end{array}$ \\
\hline$\Delta T A$ & & $\begin{array}{c}0.324 * * * \\
(2.9)\end{array}$ & $\begin{array}{c}0.321 * * * \\
\quad(3.2)\end{array}$ & & $\begin{array}{c}0.854 * * * \\
(4.2)\end{array}$ & $\begin{array}{c}0.924 * * * \\
(4.9)\end{array}$ \\
\hline$\triangle H F S$ & & $\begin{array}{c}0.027 \\
(0.3)\end{array}$ & $\begin{array}{c}0.021 \\
(0.3)\end{array}$ & & $\begin{array}{c}0.388 * * \\
(2.1)\end{array}$ & $\begin{array}{c}0.486^{* * *} * \\
(2.7)\end{array}$ \\
\hline$C F I$ & $\begin{array}{c}-0.127 * * \\
(-2.4)\end{array}$ & $\begin{array}{c}-0.114 * * \\
(-2.2)\end{array}$ & & $\begin{array}{c}-0.039 \\
(-0.4)\end{array}$ & $\begin{array}{c}0.016 \\
(0.2)\end{array}$ & \\
\hline$C F F$ & $\begin{array}{c}-0.098 * \\
(-1.9)\end{array}$ & $\begin{array}{c}-0.092 * \\
(-1.8)\end{array}$ & & $\begin{array}{c}-0.157 * \\
(-1.7)\end{array}$ & $\begin{array}{l}-0.135 \\
(-1.5)\end{array}$ & \\
\hline NONOP & & & $\begin{array}{c}-0.089 * \\
(-1.9)\end{array}$ & & & $\begin{array}{l}-0.108 \\
(-1.4)\end{array}$ \\
\hline Adj. $\mathrm{R}^{2}$ & 0.055 & 0.068 & 0.070 & -- & -- & -- \\
\hline Likelihood & -- & -- & -- & & & \\
\hline Ratio Test $\left(x^{2}\right)$ & & & & 61.33 & 35.36 & 57.62 \\
\hline \# Observations & 330 & 330 & 330 & 226 & 226 & 226 \\
\hline
\end{tabular}


TABLE 4

(continued)

Panel B: t-tests of Differences of Coefficients in Equation (5)

\begin{tabular}{cccc}
\hline & $\underline{T A}$ & $\underline{H F S}$ & $\underline{\text { NONOP }}$ \\
OP & $1.50^{*}$ & $3.00^{* * * * *}$ & $3.34^{* * *}$ \\
TA & & $2.55^{* * *}$ & 1.00
\end{tabular}

Panel C: t-tests of Differences of Coefficients in Equation (8)

\begin{tabular}{cccc}
\hline & $\underline{T A}$ & $\underline{H F S}$ & $\frac{N O N O P}{4.92^{* * *}}$ \\
$O P$ & $2.48^{* * *}$ & $3.12^{* * *}$ & $4.56^{* * *}$ \\
$T A$ & & $1.90^{* *}$ & $2.59^{* * *}$ \\
\hline
\end{tabular}

$* * *, * *$, and $*$ indicate statistical significance at $1 \%, 5 \%$ and $10 \%$, respectively, in a one-tailed test if directional predictions are made and a two-tailed test otherwise.

To mitigate serial dependence of residuals, the estimation of the future cash flow models includes (untabulated) fixed effects for each bank and allows each bank's residuals to follow the same AR(1) process.

See the notes to Table 2 for description of the variables. 
TABLE 5

Incremental Explanatory Power of Trading Revenues

$$
\begin{aligned}
& \mathrm{R}_{\mathrm{t}}=\mathrm{a}+\mathrm{b}_{1} \mathrm{OP}_{\mathrm{t}}+\mathrm{b}_{2} \Delta \mathrm{TA}_{\mathrm{t}}+\mathrm{b}_{3} \Delta \mathrm{HFS}_{\mathrm{t}}+\mathrm{b}_{4} \mathrm{NONOP}_{\mathrm{t}}+\mathrm{b}_{5} \mathrm{TR}_{\mathrm{t}}+\mathrm{e}_{\mathrm{t}} \\
& \mathrm{FCFO}_{\mathrm{t}}=\mathrm{a}+\mathrm{b}_{1} \mathrm{OP}_{\mathrm{t}}+\mathrm{b}_{2} \Delta \mathrm{TA}_{\mathrm{t}}+\mathrm{b}_{3} \Delta \mathrm{HFS}_{\mathrm{t}}+\mathrm{b}_{4} \mathrm{NONOP}_{\mathrm{t}}+\mathrm{b}_{5} \mathrm{TR}_{\mathrm{t}}+\mathrm{e}_{\mathrm{t}}
\end{aligned}
$$

\begin{tabular}{|c|c|c|}
\hline & $\underline{\text { Returns }}$ & $\underline{\text { Future Cash Flows }}$ \\
\hline \multirow[t]{2}{*}{ Intercept } & $0.160 * * *$ & $0.326^{* * *}$ \\
\hline & & \\
\hline \multirow[t]{2}{*}{$O P$} & $0.556 * * *$ & $2.058 * * *$ \\
\hline & (3.3) & $(4.9)$ \\
\hline \multirow[t]{2}{*}{$\Delta T A$} & $0.237 * *$ & $0.979 * * *$ \\
\hline & $(2.2)$ & $(5.0)$ \\
\hline \multirow[t]{2}{*}{$\triangle H F S$} & 0.004 & $0.523 * * *$ \\
\hline & $(0.1)$ & $(3.0)$ \\
\hline \multirow[t]{2}{*}{ NONOP } & $-0.081 *$ & $-0.153 *$ \\
\hline & $(-1.7)$ & $(-1.8)$ \\
\hline \multirow[t]{2}{*}{$T R$} & $0.723 * *$ & .929 \\
\hline & $(2.0)$ & $(.8)$ \\
\hline Adj. $R^{2}$ & 0.078 & -- \\
\hline Likelihood RatioTest $\left(x^{2}\right)$ & -- & 57.08 \\
\hline \# Observations & 330 & 226 \\
\hline
\end{tabular}


TABLE 6

Distinguishing Dealer and Non-Dealer Banks

$$
\begin{aligned}
& \mathrm{R}_{\mathrm{t}}=\mathrm{a}+\mathrm{a}_{\mathrm{D}} \mathrm{D}+\mathrm{b}_{1} \mathrm{OP}_{\mathrm{t}}+\mathrm{b}_{2} \Delta \mathrm{TA}_{\mathrm{t}}+\mathrm{b}_{3} \Delta \mathrm{HFS}_{\mathrm{t}}+\mathrm{b}_{4} \mathrm{NONOP}_{\mathrm{t}} \\
& +\mathrm{b}_{5} \mathrm{D}^{*} \mathrm{OP}_{\mathrm{t}}+\mathrm{b}_{6} \mathrm{D}^{*} \Delta \mathrm{TA}_{\mathrm{t}}+\mathrm{b}_{7} \mathrm{D}^{*} \Delta \mathrm{HFS}_{\mathrm{t}}+\mathrm{b}_{8} \mathrm{D}^{*} \mathrm{NONOP}_{\mathrm{t}}+\mathrm{e}_{\mathrm{t}} \\
& \mathrm{FCFO}_{\mathrm{t}}=\mathrm{a}+\mathrm{a}_{\mathrm{D}} \mathrm{D}+\mathrm{b}_{1} \mathrm{OP}_{\mathrm{t}}+\mathrm{b}_{2} \Delta \mathrm{TA}_{\mathrm{t}}+\mathrm{b}_{3} \Delta \mathrm{HFS}_{\mathrm{t}}+\mathrm{b}_{4} \mathrm{NONOP}_{\mathrm{t}} \\
& +\mathrm{b}_{5} \mathrm{D}^{*} \mathrm{OP}_{\mathrm{t}}+\mathrm{b}_{6} \mathrm{D}^{*} \Delta \mathrm{TA}_{\mathrm{t}}+\mathrm{b}_{7} \mathrm{D}^{*} \Delta \mathrm{HFS}_{\mathrm{t}}+\mathrm{b}_{8} \mathrm{D}^{*} \mathrm{NONOP}_{\mathrm{t}}+\mathrm{e}_{\mathrm{t}}
\end{aligned}
$$

\begin{tabular}{|c|c|c|}
\hline & $\underline{\text { Returns }}$ & Future Cash Flows \\
\hline Intercept & $\begin{array}{l}0.192 * * * \\
\quad(6.7)\end{array}$ & $\begin{array}{c}0.363^{* * *} \\
(2.8)\end{array}$ \\
\hline$O P$ & $\begin{array}{l}0.502 * * * \\
\quad(2.8)\end{array}$ & $\begin{array}{c}1.068 * * \\
(2.0)\end{array}$ \\
\hline$D$ & $\begin{array}{c}-0.227 * * * \\
(-2.7)\end{array}$ & $\begin{array}{c}0.132 \\
(0.4)\end{array}$ \\
\hline$\triangle T A$ & $\begin{array}{l}0.319 * * * \\
\quad(2.4)\end{array}$ & $\begin{array}{c}0.273 \\
(0.9)\end{array}$ \\
\hline$\triangle H F S$ & $\begin{array}{c}-0.023 \\
(-0.3)\end{array}$ & $\begin{array}{l}0.359 * * \\
\quad(1.9)\end{array}$ \\
\hline NONOP & $\begin{array}{l}-0.074 \\
(-1.5)\end{array}$ & $\begin{array}{c}-0.095 \\
(-1.1)\end{array}$ \\
\hline$D * O P$ & $\begin{array}{l}1.488 * * * \\
(2.7)\end{array}$ & $\begin{array}{c}2.487 * * \\
\quad(2.0)\end{array}$ \\
\hline$D * \Delta T A$ & $\begin{array}{c}-0.097 \\
(-0.4)\end{array}$ & $\begin{array}{c}0.611 * \\
(1.3)\end{array}$ \\
\hline$D^{*} \Delta H F S$ & $\begin{array}{l}0.783 * * \\
\quad(2.5)\end{array}$ & $\begin{array}{l}1.316^{* *} \\
(2.3)\end{array}$ \\
\hline$D * N O N O P$ & $\begin{array}{c}-0.013 \\
(-0.1)\end{array}$ & $\begin{array}{c}0.066 \\
(0.3)\end{array}$ \\
\hline Adjusted $\mathrm{R}^{2}$ & 0.096 & -- \\
\hline Likelihood RatioTest $\left(\chi^{2}\right)$ & -- & 50.23 \\
\hline \# Observations & 330 & 226 \\
\hline
\end{tabular}




\section{REFERENCES}

Ali, A. 1994. The Incremental Information Content of Earnings, Working Capital from Operations, and Cash Flows. Journal of Accounting Research 32: 61-74.

Barth, M. 1994. Fair Value Accounting: Evidence from Investment Securities and the Market Valuation of Banks. The Accounting Review 69: 1-25.

Barth, M., W. Beaver, and M. Wolfson. 1990. Components of Earnings and the Structure of Bank Share Prices. Financial Analysts Journal May-June: 53-60.

Barth, M., D. Cram, and K. Nelson. 2001. Accruals and the Prediction of Future Cash Flows. The Accounting Review 76: 27-58.

Beaver, W., and M. McNichols. 2001. Do Stock Prices of Property Casualty Insurers Fully Reflect Information about Earnings, Accruals, Cash Flows, and Development? Review of Accounting Studies 6: 197-220.

Bernard, V., and T. Stober. 1989. The Nature and Amount of Information Reflected in Cash Flows and Accruals. The Accounting Review 64: 624-652.

Bowen, R., D. Burghstahler, and L. Daley. 1987. The Incremental Information Content of Accrual Versus Cash Flows. The Accounting Review 62: 723-747.

Cheng, Q., P. Frischmann, and T. Warfield. 2000. The Market Perception of Corporate Claims. Working paper, University of Wisconsin.

Dechow, P. 1994. Accounting Earnings and Cash Flows as Measures of Firm Performance: The Role of Accounting Accruals. Journal of Accounting and Economics 18: 3-42.

Dechow, P., S. P. Kothari, and R. Watts. 1998. The Relation between Earnings and Cash Flows. Journal of Accounting and Economics 25: 133-168.

Fairfield, P., R. Sweeney, and T. Yohn. 1996. Accounting Classification and the Predictive Content of Earnings. The Accounting Review 71: 337-355.

Financial Accounting Standards Board, 1978, Statement of Financial Accounting Concepts No. 1, Objectives of Financial Reporting by Business Enterprises.

Financial Accounting Standards Board, 1986, Statement of Financial Accounting Standards No. 91, Accounting for Nonrefundable Fees and Costs Associated with Originating or Acquiring Loans and Initial Direct Costs of Leases.

Financial Accounting Standards Board, 1987, Statement of Financial Accounting Standards No. 95, Statement of Cash Flows. 
Financial Accounting Standards Board, 1989, Statement of Financial Accounting Standards No. 102, Statement of Cash Flows - Exemption of Certain Enterprises and Classification of Cash Flows from Certain Securities Acquired for Resale, February.

Financial Accounting Standards Board, 1993, Statement of Financial Accounting Standards No. 115, Accounting for Certain Investments in Debt and Equity Securities.

Financial Accounting Standards Board, 1994, Statement of Financial Accounting Standards No. 119, Disclosure about Derivative Financial Instruments and Fair Value of Financial Instruments.

Financial Accounting Standards Board, 2003, Statement of Financial Accounting Standards No. 149, Amendment of Statement 133 on Derivative Instruments and Hedging Activities.

Foster, G. 1977. Valuation Parameters of Property-Liability Companies. The Journal of Finance 32: 823-835.

G4+1. 1999. Reporting Financial Performance. Discussion Paper. August.

Hopkins, P. 1996. The Effect of Financial Statement Classification of Hybrid Financial Instruments on Financial Analysts' Stock Price Judgments. Journal of Accounting Research 19: 33-50.

Jorion, P. How Informative are Value-at-Risk Disclosures. The Accounting Review 77: 911-931.

Kothari, S. P. 2001. Capital Markets Research in Accounting. Journal of Accounting and Economics 31: 105-231.

Linsmeier, T., C. Shakespeare, and T. Sougiannis. 2000. Liability/Equity Classifications and Shareholder Valuation. Working paper, Michigan State University.

Lipe, R. 1986. The Information Contained in the Components of Earnings. Journal of Accounting Research 24: 37-64.

Liu, C., S. Ryan, and H. Tan. 2004. How Banks' Value-at-Risk Disclosures Predict Their Total and Priced Risk: Effects of Bank Technical Sophistication and Learning Over Time. Review of Accounting Studies 9: 265-294.

Livnat, J., and P. Zarowin. 1990. The Incremental Information Content of Cash Flow Components. Journal of Accounting and Economics 13: 25-46.

Miller, M., and F. Modigliani. 1958. The Cost of Capital, Corporation Finance, and the Theory of Investment. American Economic Review 48: 261-297.

Miller, M., and K. Rock. 1985. Dividend Policy under Asymmetric Information. Journal of Finance 40: 1031-1052. 
Nurnberg, H. 1993. Inconsistencies and Ambiguities in Cash Flow Statements under FASB Statement No. 95. Accounting Horizons 7: 60-75.

Ohlson, J., and S. Penman. 1992. Accounting Measurement, Price-Earnings Ratio, and the Information Content of Security Prices. Journal of Accounting, Auditing, and Finance 7: 553-573.

Rayburn, J. 1986. The Association of Operating Cash Flow and Accruals with Security Returns. Journal of Accounting Research 24: 112-138.

Ryan, S. 2002. Financial Instruments and Institutions: Accounting and Disclosure Rules. John Wiley \& Sons: Hoboken.

Wahlen, J. 1994. The Nature and Information in Commercial Bank Loan Loss Disclosures. The Accounting Review 69: 455-478.

Wilson, G. P. 1986. The Relative Information Content of Accruals and Cash Flows: Combined Evidence at the Earnings Announcement and Annual Report Release Date. Journal of Accounting Research 24: 165-200.

Wilson, G. P. 1987. The Incremental Information Content of Accrual and Funds Components of Earnings after Controlling for Earnings. The Accounting Review 62: 293-322. 